\title{
The Messinian Salinity Crisis in the Dacic Basin (SW Romania) and early Zanclean Mediterranean - Eastern Paratethys high sea-level connection
}

\author{
Jean-Pierre Suc $^{\mathrm{a}}{ }^{*}$, Damien Do Couto ${ }^{\mathrm{a}, \mathrm{b}}$, Mihaela Carmen Melinte-Dobrinescu ${ }^{\mathrm{c}}$, \\ Rodica Macaleț $^{\mathrm{d}}$, Frédéric Quillévérée ${ }^{\mathrm{e}}$ Georges Clauzon ${ }^{\mathrm{e}}$, Istvan Csato ${ }^{\mathrm{g}}$, \\ Jean-Loup Rubino ${ }^{\text {h }}$, Speranta-Maria Popescu ${ }^{\mathrm{i}}$
}

a, Institut des Sciences de la Terre de Paris (UMR 7193 CNRS), Université Pierre et Marie Curie, 4 place Jussieu, case 117, 75252 Paris Cedex 05, France

b, Université d'Orléans, CNRS/INSU, Institut des Sciences de la Terre d'Orléans - UMR6113, Campus Géosciences, 1A rue de la Férollerie, 45071 Orléans Cedex 2, France

c, National Institute of Marine Geology and Geoecology, 23-25 Dimitrie Onciul street, P.O. Box 34-51, 70318

Bucharest, Romania

d, National Institute of Hydrology and Water Management, 97 Bucuresti-Ploiesti Road, 013686 Bucharest, Romania

e, Laboratoire de géologie de Lyon : Terre, Planètes, Environnement (UMR 5276 CNRS), Université Lyon 1, 27-43 boulevard du 11 Novembre 1918, 69622 Villeurbanne Cedex, France

f, C.E.R.E.G.E. (UMR 6635 CNRS), Université Paul Cézanne, Europôle de l'Arbois, BP 80, 13545 Aix-enProvence Cedex 04, France

g, Department of Geology, Collin College, 2800 Spring Creek Pkwy, Plano TX 75075, United States of America h, TOTAL, TG/ISS, CSTTF, Avenue Laribeau, 64018 Pau Cedex, France 
i, Institut de Physique du Globe de Paris et Université Paris Diderot (Sorbonne Paris-Cité), UMR CNRS 7154, 1 rue Jussieu, 75238 Paris Cedex 05, France

*Corresponding author. Tel.: +33682143526,+33478973305

E-mail address: jeanpierre.suc@gmail.com (J.-P. Suc).

\section{Abstract}

New field observations and fossil analyses complete and clarify the strong impact of the Mediterranean sea-level changes linked to the peak of the Messinian Salinity Crisis on the Dacic Basin in southwestern Romania. In addition to the Gilbert-type fan delta already evidenced along the Danube River in the area of Turnu Severin, a new Gilbert-type fan delta is described northward. Early Zanclean bottomset beds are evidenced and dated based on nannofossils at the junction of the two coalescing Gilbert-type fan deltas. A clear sedimentological, morphological and chronologic differentiation is established in the area between the Carpathians Late Miocene piedmont alluvial fans and the early Zanclean Gilberttype fan deltas. The early Zanclean age of the Hinova clays, where the bottomset beds of the Gilbert-type fan deltas are mostly developed, is confirmed by the occurrence of nannofossil markers of Subzone NN12b and a Bosphorian mollusk macrofauna. Early Zanclean inflow of Mediterranean marine waters into the Dacic Basin is also supported by the record of planktonic foraminifers. In the Dacic Basin, the Messinian Salinity Crisis resulted in the cutting of the Iron Gates by a Carpathians river. Fluvial erosion also affected the residual Pannonian Basin and probably catched the palaeo-Tisza River which contributed to the erosion of the Iron Gates and to the fluvial drainage of the partly desiccated Dacic Basin. Arguments are reinforced in favor of a marine gateway between the Mediterranean and Dacic Basin through the Balkans before and after the Messinian Salinity Crisis. 
Key-words: Fluvial network - Mediterranean sea-level changes - Gilbert-type fan delta Eastern Paratethys - Pontian palaeogeography.

Highlights: > Two earliest Pliocene Gilbert-type fan deltas occur in the Turnu Severin area. > They are separated from the Late Miocene Carpathians piedmont by an erosional contact. > Messinian fluvial erosion cut the Iron Gates and impacted also the Pannonian Basin. > Earliest Pliocene Mediterranean marine inflows entered the Dacic Basin (Bosphorian). > A marine gateway crossed the Balkans before and after the Messinian Salinity Crisis.

\section{Introduction}

Up to the late nineties, the research on the relationships between the Mediterranean and Paratethys during the Late Neogene focused on the building of stratigraphic correlations (Seneš, 1973; Marinescu et al., 1998). This matter became crucial when Late Miocene and Early Pliocene marine nannoplankton influxes were discovered in the Eastern Paratethys (Fig. 1a; Mărunţeanu and Papaianopol, 1995; Semenenko and Olejnik, 1995; Mărunţeanu and Papaianopol, 1998; Drivaliari et al., 1999; Clauzon et al., 2005; Snel et al., 2006). When compared to the already evidenced entrance of Paratethyan organisms into the Mediterranean known as the "Lago Mare" facies (Gignoux, 1950; Ruggieri, 1962; see for recent syntheses: Orszag-Sperber, 2006; Popescu et al., 2009; and references therein) such occurrences stimulated new research and the direction of water in- and outflows between the Paratethys and Mediterranean was intensely discussed (CIESM, 2008). In the area of Turnu Severin (Dacic Basin, SW Romania; Fig. 1), Clauzon et al. (2005) evidenced a Bosphorian Gilberttype fan delta, which was referred to the early Zanclean based upon Mediterranean nannofossils and magnetostratigraphy for its subaqueous portion and upon mammals and magnetostratigraphy for its subaerial portion (see also Popescu et al., 2006). An erosional 
contact was observed between such a fan delta and the older rocks which, as a consequence, was referred to the Messinian Erosional Surface (Clauzon et al., 2005).

The interpretation of the Turnu Severin deposits by Clauzon et al. (2005) has been questioned based on two lines of reasoning. (1) Jipa (1997) and Olteanu and Jipa (2006) interpreted them as a piedmont alluvial fan facies derived from the uplift of the Carpathians. (2) Krijsman et al. (2010) dated the marine influx from the Mediterranean as early Odessian (Early Pontian) and considered the Turnu Gilbert-type fan delta as pre-Meotian (see Table 1 for the compared standard and Eastern Paratethys chronostratigraphic scales).

In this paper, we provide new data from this area (Fig. 2) in order to (1) better differentiate the Turnu Severin Gilbert-type fan delta from the Carpathian piedmont alluvial fans, and (2) clarify its age.

\section{Previous information on the Turnu Severin series}

Clauzon et al. (2005) proposed an early Zanclean age for the bottomset beds of the Turnu Severin Gilbert-type fan delta exposed at Hinova. The lowermost nannoflora from the thin coquina at Hinova (locality 7 in Figure 2, here called Hinova a) was studied in 1998 by M. Mărunţeanu and published in Clauzon et al. (2005). It contained Reticulofenestra minuta, $R$. pseudoumbilicus, $R$. minutula, $R$. doronicoides, Calcidiscus leptoporus, Coccolithus pelagicus, Helicosphaera kamptneri (Clauzon et al., 2005). Such an assemblage was considered to immediately postdate the Messinian Salinity Crisis (MSC) with respect to Raffi et al. (2006), but we did not unambiguously demonstrate the proposed earliest Zanclean age (Clauzon et al., 2005). This coquina level immediately overlies an oxidized thin yellow sand (Popescu, 2001). Respectively, $10 \mathrm{~m}$ and $15 \mathrm{~m}$ above, two additional samples provided a similar nannoflora associated with Sphenolithus abies, Amaurolithus primus and Nicklithus (ex. Amaurolithus) amplificus, the latter (highest occurrence at ca. 5.9 Ma; Raffi et al., 2006) 
being considered as reworked by Clauzon et al. (2005). Palaeomagnetic analysis on four samples from the light grey sandy clays of the Hinova a section also yielded results consistent with the proposed earliest Zanclean age (Popescu et al., 2006). Table 1 provides the presentday accepted standard chronostratigraphy for the last 15 Ma (Lourens et al., 2004) and its equivalent in the Eastern Paratethys (Vasiliev et al., 2004; Krijgsman et al., 2010).

Krijgsman et al. (2010, p. 188) questioned this age on the basis of the geological maps of Turnu Severin (Savu and Ghenea, 1967) and Baia de Aramă (Năstăseanu and Bercia, 1968) where these deposits are considered as pre-Maeotian (i.e. older than at least $8 \mathrm{Ma}$; Table 1). However, the bottomset beds of the Turnu Severin Gilbert-type fan delta are mapped as Pontian deposits (Fig. 2; Savu and Ghenea, 1967). Savu and Ghenea (1967) specify that between Bistriţa and Pd. Stîrmina (Fig. 2), (1) these Pontian deposits are constituted of Lower Pontian ${ }^{1}$ clays conformably overlain by Upper Pontian (Bosphorian) clays both with a typical mollusk fauna (Table 2), and (2) the Bosphorian clays are covered by thick whitish sands (80$100 \mathrm{~m})$. However, according to Marinescu (1978), only Bosphorian clays are exposed between Şimian and Bistriţa, i.e. very close to the Hinova a section (Fig. 2). Attribution by Krijsgman et al. (2010) of a Bosphorian age to the Hinova a section (Fig. 2) is challenged by the mollusk fauna identified by I. Papaionopol in 1998 with F. Marinescu and published in Clauzon et al. (2005) including the Bosphorian markers Limnocardium emarginatum, L. petersi, Dreissena rostriformis, Dreissenomya aperta, Phyllocardium planum planum (Table 2). At Hinova, Clauzon et al. (2005) showed that the whitish sands are the foreset beds of the Turnu Severin Gilbert-type fan delta. The marine-continental transition of such a fan delta

\footnotetext{
${ }^{1}$ This Lower Pontian probably includes the Odessian and Portaferrian regional stages (Table 1) as the mollusk fauna listing shows both Paradacna abichi (running from Odessian to earliest Bosphorian) and Congeria rhomboidea rhomboidea (marker of Portaferrian) (Table 2).
} 
occurs at an elevation of $220 \mathrm{~m}$, marked by the lowermost lignite of the Late Neogene series, which is overlain by whitish sands of the topset beds. Northward, sandy foreset beds are replaced by alternating lignites - clays - sands magnetostratigraphically dated as Early Pliocene (Popescu et al., 2006).

Savu and Ghenea (1967) did not extend the Bosphorian age of the Bistriţa - Pd. Stîrmina upper clays to the pebbly and sandy foreset beds exposed from Gura Văii to Turnu Severin probably because the concept of Gilbert-type fan deltas was not yet widely developed. They considered a pre-Maeotian age (Table 1) for the Gura Văii - Turnu Severin pebbly and sandy beds because they are similar to well-dated deposits northward in the region. Krijgsman et al. (2010) rejected the Bosphorian age of the Hinova upper clays and preferred a pre-Maeotian age for the whole Gilbert-type fan delta of Turnu Severin. They concluded that there was no marine influx from the Mediterranean into the Dacic Basin during the Bosphorian (Table 1). However, this conclusion is contradicted by the occurrence of Ceratolithus acutus (1) at 388 $\mathrm{m}$ depth in the Ţicleni well (area of Tîrgu Jiu; Fig. 1b) in clays overlying Portaferrian deposits (Drivaliari et al., 1999; Popescu et al., 2006) and belonging to the lateral extension of the bottomset beds of the Gilbert-type fan delta of Turnu Severin (Clauzon et al., 2005), and (2) similarly in other sections from the northern Dacic Basin (Bădislava close to Rîmnicu Vîlcea, Valea Vacii close to Buzău; Fig. 1b; Mărunţeanu and Papaianopol, 1998; Snel et al., 2006).

\section{Piedmont alluvial fan and Gilbert-type fan delta deposits}

The studied region is at the foot of the southwestern part of the Carpathians Mountains where piedmont alluvial fans are frequent (Jipa and Olariu, 2009). Here also, the MSC is at the origin of a Zanclean Gilbert-type fan delta (Clauzon et al., 2005) as in many places around the Mediterranean. Accordingly, it is necessary to recall the respective characteristics of these nearby sedimentary constructions in order to establish their indisputable distinction. 
An aggrading piedmont is a geomorphological entity which results from an alluvial fan made of subaerial deposits originating from erosion of a nearby, previously uplifted relief (Harvey et al., 2005). It is cone-shaped and opens out away from the mountain. Sediments are constituted by relatively unorganized, mixed coarse to fine grained elements (Fig. 3a) which were solely forced by the repeated detritic discharges caused by torrential floods. Hence, rounded or angular pebbles may be juxtaposed with sands and clays, as shown in Figures 4ab.

A Gilbert-type fan delta (Gilbert, 1885, 1890) results from a strong subaerial erosion followed by a very fast rise in water-level then maintained by some stability. It is constituted by two superposed alluvial prisms (Fig. 3b): (1) the lower prism, downstream open, prograding in subaqueous conditions; and (2) the upper prism, upstream open, aggrading in subaerial conditions. Because of its subaqueous context of sedimentation, the lower prism is constituted by leached and sorted terrigenous elements: clayey particles are mostly deposited relatively far from the river mouth, whereas well-rounded pebbles concentrate just after the river outlet (Figs. 4c-d), gravels and sands being dominantly deposited in between (Figs. 4ef). The coarse to medium-size clastic material forms foreset beds (Fig. 3b), which are characterized by a sedimentary dip up to $25^{\circ}$. The reason for this characterization is the prograding process (often confused with a tectonic dip) with obvious sigmoid sedimentary patterns (Fig. 5), and which are constrained both by the available space and the river input. The fine clayey terrigenous material constitutes the bottomset beds where micro- and macrofossils may accumulate (Fig. 3b). The upper prism is made of almost uniformly mixed detritic material (pebbles to sands and clays) showing from place to place cross-bedded stratifications (Fig. 3b). It corresponds to the alluvial coastal plain of the river. 
Despite their clear differences in deposit composition and organization, piedmonts (alluvial fans) and Gilbert-type fan deltas are often confused, especially when sedimentary dips of foreset beds are misinterpreted as resulting from tectonic tilting.

\section{New data on the Middle Miocene piedmont alluvial fans and Zanclean Gilbert-type}

\section{fan deltas in the Turnu Severin area}

Piedmont alluvial fans stretch at the foot of the Carpathians Mountains. They are considered to be pre-Maeotian since beyond the Turnu Severin region and according to Savu and Ghenea (1967) they are directly overlain by Maeotian sediments. The age of the early development of such alluvial fans can be specified thanks to a Mediterranean nannoflora identified by M. Mărunţeanu in five clayey horizons that we sampled in 1998 at Dîlbociţa (locality 11 in Figure 2: 444' $50.2^{\prime} \mathrm{N}, 2^{\circ} 44^{\prime} 41.3$ ”E) close to Ilovăţ (i.e. just below the piedmont alluvial fan deposits; Figs. 6, 7). These samples yielded Calcidiscus leptoporus, Sphenolithus heteromorphus, S. moriformis, Discoaster deflandrei, Calcidiscus macintyrei, Reticulofenestra minuta, R. pseudoumbilicus, Helicosphaera kamptneri, and Coccolithus pelagicus, among other taxa. Co-occurring S. heteromorphus, C. macintyrei and D. deflandrei indicate a late Langhian - early Serravallian age (Zone NN5; Martini, 1971; Raffi et al., 2006). Accordingly, the alluvial fan of the Carpathians piedmont deposited between ca. 14 to 9 Ma with respect to the chronologies of Lourens et al. (2004) and Vasiliev et al. (2004), for the Mediterranean and Eastern Paratethys, respectively (Table 1).

The thick foreset beds (Fig. 5a) of the Gilbert-type fan delta described by Clauzon et al. (2005) are exposed along the Danube River, especially on its left bank and at Kladusnica near Kladovo (locality 3 in Figure 2) in Serbia. This sedimentary complex at Gura Văii has an erosional base $\left(44^{\circ} 40^{\prime} 7.1^{\prime} \mathrm{N}, 2^{\circ} 33^{\prime} 42.2^{\prime}\right.$ E; Figs. 7, 8) and shows a progressive passage from conglomeratic foreset beds to gravelly-sandy foreset beds (well-exposed at the abandoned 
swimming pool of Turnu Severin: $\left.44^{\circ} 37^{\prime} 58.1^{\prime \prime} \mathrm{N}, 22^{\circ} 35^{\prime} 49.9^{\prime \prime} \mathrm{E}\right)$. The latter is followed by bottomset beds that we observed at Brezniţa-Ocol $\left(44^{\circ} 40^{\prime} 44.9^{\prime \prime} \mathrm{N}, 22^{\circ} 36^{\prime} 57.4^{\prime \prime} \mathrm{E}\right.$; locality 5 in

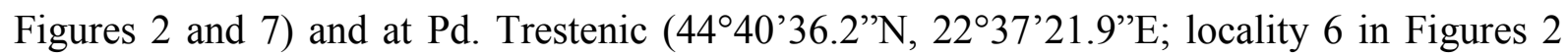
and 7). In the area of Brezniţa-Ocol, the contact between the clayey bottomset beds and sandy forest beds is marked by water springs. Such a succession of facies indicates a Gilbert-type fan delta, which was necessarily built by a powerful river that had a similar course to the present Danube River downstream the Iron Gates. At Gura Văii (i.e. in the proximal part of the Gilbert-type fan delta) there is no doubt on the erosional contact between the pebbly foreset beds and a polygenic and heterometric breccia overlying the Cretaceous limestones (Fig. 8a, b). This breccia (Fig. 8c) is a coarse slope deposit of post-Sarmatian age as it overlies the Sarmatian fossiliferous limestones at Vărănic where it includes some reworked blocks of

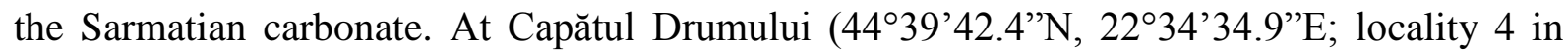
Figure 2; Fig. 7), the pebbly foreset beds reach an altitude of $329 \mathrm{~m}$ and are nested within a series made of Cretaceous carbonates overlain by Sarmatian carbonates and the abovementioned breccias (highest altitude: $381 \mathrm{~m}$ ). The Zanclean age of this Gilbert-type fan delta was deduced from the nannoflora found at Hinova a (locality 7 in Figure 2; Clauzon et al., 2005). But the age of this locality was not robust enough because (1) the relatively long distance devoid of exposed Neogene deposits from Turnu Severin (15 km), and (2) the absence of unquestionable biostratigraphic marker. Sample 4 from the clayey bottomset beds exposed on a thickness of $4 \mathrm{~m}$ at Pd. Trestenic (Fig. 9a), i.e. fully within the Gilbert-type fan delta complex, yielded Discoaster brouweri, Reticulofenestra pseudoumbilicus, Sphenolithus abies, Coccolithus pelagicus, Ceratolithus larrymayeri, Calcidiscus leptoporus, C. macintyrei, Helicosphaera carteri, H. stalis and small reticulofenestrids. Ceratolithus larrymayeri (Plate 1, Fig. 3-4) has a very short range (5.34 - 5.1 Ma: Raffi et al., 1998, 2006). Its occurrence is therefore an unquestionable argument for dating the Gilbert-type fan delta 
from the early Zanclean (Table 1). Hence, the erosional surface which separates the Gilberttype fan delta from older sediments, observed at Gura Văii and Capătul Drumului, is undoubtedly the Messinian Erosional Surface as proposed by Clauzon et al. (2005).

A new field investigation in the area allowed us to discover another Gilbert-type fan delta along the Topolnhiţa River, the foreset beds of which (Fig. 5b) are well-exposed on both banks between Baloteşti (locality 10; Figs. 2, 7) and Izvoru Bîrzii (locality 9; Figs. 2, 7). This Gilbert-type fan delta has also an early Zanclean age according to the nannoflora of Pd. Trestenic. The bottomset beds exposed in the area of Pd. Trestenic belong to the two coalescing Gilbert-type fan deltas. At Baloteşti, the Topolniţa Gilbert-type fan delta is clearly nested within the piedmont alluvial fan fed by the nearby metamorphic basement (Figs. 10a, b, c, d). Here, the distinct light grey sandy foreset beds of the Topolniţa Gilbert-type fan delta are pinned against the piedmont reddish heterogenous deposits through a clearly erosional contact (Figs. 10e), which is therefore considered as the Messinian Erosional Surface (Fig. $10 b)$.

The associated power of two rivers springing from the Carpathians Mountains explains the long distance transport of clays and sands. South of Hinova, a second clayey section has been

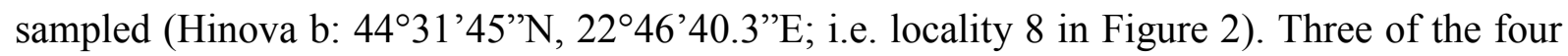
samples yielded Reticulofenestra pseudoumbilicus, Amaurolithus sp., Coccolithus pelagicus, Calcidiscus leptoporus, C. macintyrei and small reticulofenestrids. Among these samples, sample 3 originates from the coquina level shown in Figure 9f. Sample 4 (Fig. 9f) yielded in addition Sphenolithus abies, Triquetrorhabdulus rugosus and Ceratolithus acutus (Plate 1, Figs. 1-2), which together indicate an age comprised between 5.345 and 5.279 Ma (Raffi et al., 2006) for these bottomset beds. The early Zanclean age of the two Gilbert-type fan deltas is thus reinforced. Constituted by Phyllocardium sp., Pontalmyra drobetica, P. sabbae and Congeria sp. (Fig. 9h), the mollusk macrofauna observed in this section (Fig. 9g) is 
characteristic of the Bosphorian regional Substage (Table 2), which is in agreement with the early Zanclean age indicated by nannofossils (Table 1). The influx of early Zanclean Mediterranean marine waters into the Dacic Basin, already evidenced by nannofossils and dinoflagellate cysts at Hivona a (Clauzon et al., 2005), is then confirmed by the presence of marker nannofossils at Hinova b. It is also reinforced by the presence of small $(<125 \mu \mathrm{m})$ specimens of microperforate trochospiral planktonic foraminifera (Tenuitella-Tenuitellinata sp.; Plate 1, Figs. 5-6) in Hinova b samples. The co-occurrence of these small Globigerinitidae with the calcareous nannoplankton species $S$. abies, T. rugosus and C. acutus in sample 4 of the Hinova b section indicates that their presence in situ can be considered as normal and indicative of marine connections with the Mediterranean during the early Zanclean.

On the basis of all the available data in the area of Turnu Severin, it is now possible to propose a reconstruction of its evolution during the time-interval $12-5 \mathrm{Ma}$ (Fig. 12). The uplift of the Carpathians Mountains caused the development of the piedmont alluvial fans by local rivers (Fig. 12a), the residual expansion of which is mapped on Figure 11. The Messinian Salinity Crisis (MSC) caused a huge erosion of the previously built piedmont alluvial fan and older rocks (Fig. 12b). In particular, the Carpathians Mountains were severely cut by two rivers especially one at the origin of the Iron Gates gorge (Fig. 12b). Then, the sudden return to marine conditions related to the reconnection of the Dacic Basin with the Mediterranean Sea (Popescu et al., 2009) forced the building of two coalescing Gilbert-type fan deltas (Fig. 12c). The seismic data published by Leever et al. (2010) confirm the erosional surface which impacted the Pontian deposits as a response to the Mediterranean Messinian drawdown. The ensuing Bosphorian sea-level rise was comparatively fast and resulted in a prograding sedimentary system manifested in the exposed sections (Gilbert-type fan deltas). It was unambiguously illustrated by Leever et al. (2010: fig. 3) as exactly the opposite of the 
"transgressive system track" evoked by Krijgsman et al. (2010, p. 188 since the Bosphorian sediments are downlapping and not onlapping.

It is necessary to question again the Pontian stratigraphic continuity (including Portaferrian or not: see footnote 1) described by Savu and Ghenea (1967) in the area of Bistriţa - Pd. Stîrmina. At Hinova, within the concerned area, the clays observed in two localities (Hinova a and b) belong to the Bosphorian regional Substage. However, at Hinova a (locality 7 on Figures 2 and 11), the lowermost nannoflora provided by a coquina layer was reported to the Bosphorian (Clauzon et al., 2005), which overlies a yellow oxidized sand (20 cm thick; Fig. 9d). We suggest here that this Bosphorian layer may have been deposited just after the peak of the MSC. Because of emersion, the MSC could be expressed by the thin yellow sand and probably some gap in sedimentation. Such a superposition of apparently conformable deposits where the Messinian desiccation phase is only expressed by a sedimentary gap and some detritic thin layers has been already evidenced: (1) in interfluvial palaeoconditions such as at Intepe (Dardanelles Strait; Melinte-Dobrinescu et al., 2009); and (2) in bottomset beds of Gilbert-type fan delta deposited in axial conditions such as at Cuevas de Almanzora (Vera, Andalusia; Clauzon et al., 2009). This latter context is in agreement with the observations and data from the Hinova area where the peak of the MSC is expressed by a gap corresponding to this slight sedimentological discontinuity (Fig. 9d), which might separate the Bosphorian sediments from the older (Odessian or Portaferrian) ones.

Magneto- and cyclostratigraphy based on the pollen record yielded an age of ca. $5.38 \mathrm{Ma}$ for the base of the Hinova a section, which contains Mediterranean nannofossils (Popescu et al., 2006). This age, consistent with the proposed age for the Bosphorian regional Substage (5.5 - 4.7 Ma: Krijgsman et al., 2010; Table 1), is in agreement with a reflooding of the Mediterranean Sea anticipating the base of the Zanclean Stage (Popescu et al., 2007, 2009; 
Melinte-Dobrinescu et al., 2009; Bache et al., accepted) as defined by its GSSP (Van Couvering et al., 2000).

\section{Palaeogeographic inferences}

These results, which specify and complement those by Clauzon et al. (2005), provide new evidences for a more accurate palaeogeographic reconstruction of the Dacic Basin and nearby areas just before and after the MSC (i.e. for the time-interval 6 - 5 Ma; Fig. 13).

Mediterranean marine waters transiently entered the Dacic Basin before and just after the peak of the MSC (5.60 - 5.46 Ma). The influx of Mediterranean waters during the Portaferrain regional Substage is characterized by the presence of the calcareous coccolith taxa Discoaster quinqueramus, Nicklithus amplificus and Triquetrorhabdulus rugosus among others (Subzone NN11b: ca. 6.9 - 5.9 Ma; Raffi et al., 2006) as shown at Valea Vacii (region of Buzău) at the foot of the southeastern Carpathians (Mărunţeanu and Papaianopol, 1998; Snel et al., 2006). An almost similar nannoflora was found at Bădislava (region of Rîmnicu Vîlcea) (Snel et al., 2006). The influx of Mediterranean waters during the Bosphorian regional Substage is characterized in the same sections by the presence of Ceratolithus acutus (Subzone NN12b; Mărunţeanu and Papaianopol, 1998; Snel et al., 2006). If one also considers the areas of Turnu Severin (Clauzon et al., 2005; this paper) and Tîrgu Jiu (Drivaliari et al., 1999; Popescu et al., 2006), these two successive influxes should be considered to have impacted the entire Dacic Basin.

Leever et al. (2010) considered that the early Zanclean re-connection between the Dacic Basin and the Mediterranean Sea was forced by the sea-level rise of the Black Sea over the Scythian sill (i.e. the Reni sill: Semenenko and Olejnik, 1995) north of the Dobrogea horst area. And yet, the oldest records of Mediterranean marine micro-organisms in the deep Black Sea at DSDP Site 380 (diatoms: Schrader, 1978; dinoflagellate cysts: Popescu, 2006; 
calcareous coccoliths: Popescu et al., 2010) have been dated at 5.31 Ma (Popescu et al., 2010), an age significantly younger than their record in the Dacic Basin (5.38 Ma at Hinova). Additional arguments contradict the often suggested presence of an almost continuous exchange gateway between the Mediterranean and Eastern Paratethys in the Istanbul region before and after the MSC (Popov et al., 2006), but support the presence of such a corridor in the Balkans (Clauzon et al., 2005; Popescu et al., 2009; Bache et al., accepted):

- the absence of Paratethyan dinoflagellate cysts denoting surface-water exchanges in the early Zanclean in the Marmara Sea region (Melinte-Dobrinescu et al., 2009);

- $\quad$ the pre-Zanclean GSSP reflooding of the Aegean Sea (Melinte-Dorbinescu et al., 2009) significantly before the entrance of Mediterranean microplankton into the Black Sea (Popescu et al., 2010);

- the presence in the Thrace and Marmara region of two facing fluvial networks driving early Zanclean Gilbert-type fan deltas towards the Black Sea and the MarmaraMediterranean realm, respectively (Suc et al., 2009);

- $\quad$ and the presence of well-dated early Zanclean Gilbert-type fan deltas in the regions of Skopje and Niš (Bache et al., accepted).

The Zanclean Gilbert-type fan deltas in the area of Turnu Severin filled Messinian fluvial valleys, establishing the development of a very active erosional fluvial network as the result of the MSC. Northward, the palaeo-Topolniţa River probably drained the southeast side of the southern Carpathians Mountains. Southward of this area, due to the thick deposits at the outlet of the Iron Gates (revealed by the work done in building the Iron Gates Dam 1) (Clauzon et al., 2005), a Messinian river probably cut a large part of this gorge. It was a powerful river which drained only the southwestern side of the southern Carpathians Mountains (Fig. 13b) because the modern Alpine Danube did not exist at that time. Indeed, the Danube River reached the Vienna Basin in the Late Pliocene (Pfleiderer, 2008), which is consistent with its 
appearance in the Dacic Basin at the early Romanian (Table 1) as reported by Jipa (2009). We propose a new two-step onset of the southern Romania fluvial network: (1) in the late Messinian, a peri-Carpathians river amplified and cut the Iron Gates as a consequence of the Mediterranean sea-level drop; and (2) in the early Romanian, this river was joined by the Alpine Danube.

The development of an ancestor of the modern fluvial network in the Dacic Basin is consistent with the formation of a major erosional unconformity in the Pannonian Basin as a response to the MSC (Csato et al., 2007). The unconformity is evidenced on regional seismic profiles (Fig. 14); contrary to the proposal of Magyar and Sztano (2008), this unconformity was not controlled by faults but was generated by a major drop of the lake level. The Messinian erosion in the Pannonian Basin must have intensified the drainage by a fluvial network that we call paleo-Tisza. A connection from the Pannonian Basin toward the Dacic Basin may have been easily facilitated through two subbasins, the Makó Trough and Békés Basin (Fig. 14a). The palaeo-Tisza coming from the Pannonian Basin also contributed to cut the Iron Gates and to drain the partly desiccated Dacic Basin (Fig. 13b).

The Messinian base level fall in the Pannonian Basin induced forced regression and subsequent normal regression by lowstand prograding units (Fig. 14b) that filled the basin fast. Seismic and well log data clearly indicate a dramatic basinward shift of facies. The Pannonian Basin also underwent a tectonic inversion, which uplifted the basin margins and caused a basinward tilting as demonstrated by the seismic sections. However, this was a relatively long process up to the present, and it probably started well after the Messinian (e.g. Hámor et al., 2001; Horváth et al., 2006). Therefore, this process could not create the sudden and drastic event represented by the Messinan unconformity. The Messinian erosion is also clear in the Dacic Basin (i) along the seismic profiles published by Leever et al. (2010) and 
(ii) in wells showing a Maeotian hiatus, which roughly superposes the modern fluvial network (Clauzon et al., 2005: fig. 11).

According to seismic data in the northwestern Black Sea, the palaeo-Tisza River did not flow into the Black Sea (Gillet et al., 2007) but probably into a remnant perched lake (Clauzon et al., 2005; Leever et al., 2010; Bache et al., accepted; Fig. 13). The sea-level fall in the Dacic Basin was directly driven by the Mediterranean sea-level drop which disrupted connection through the Balkans gateway during the time-window 5.60-5.46 Ma (Clauzon et al., 2005; Popescu et al., 2009; Bache et al., accepted). As a consequence, the Messinian Tisza River, the ancestor of the main tributary of the present-day Danube, provided the isolated Dacic Basin some water supply from the Pannonian Basin through the gorge of the Iron Gates (Fig. 13b).

Very drastic environmental changes occurred in the region as a consequence of the almost complete desiccation of the Mediterranean Sea:

- The Dacic and Pannonian basins, previously connected to the Mediterranean through the Balkans gateway (Fig. 13a; Popescu et al., 2009), were impacted by a sea-level fall, the intensity of which was controlled by the altitude of the palaeo-sill probably located in the region of Skopje (Bache et al., revised). At that time, the Dacic Basin was disconnected from the Black Sea when its water-level fell below the altitude of the Scythian sill (Fig. 13a, b). The huge sea-level drop which impacted the Black Sea was probably forced by the climatic increase in dryness resulting from the Mediterranean desiccation (Fig. 13b; Favre et al. 2007; Popescu et al., 2010) ${ }^{2}$. In the southernmost

\footnotetext{
${ }^{2}$ Although discussion of climate evolution is not within the scope of this paper, we must precise that such an increase in dryness during the peak of the MSC, both suggested by mammals (Agusti et al., 2006), pollen floras (Fauquette et al., 2006) and model simulations (Favre et al., 2007; Murphy et al., 2009; Schneck et al., 2010), amplified the xeric context
} 
part of the Balkans corridor, the palaeo-Strymon River cut a deep canyon towards the Aegean Sea (Fig. 13b). At that time, another important river (probably the palaeoMaritsa River) crossed the entire Thrace Plain and cut a canyon toward the Black Sea in the area of Karacaköy (Fig. 13b; Gillet 2004; Suc et al. 2009). This fluvial canyon and its sedimentary filling by an early Zanclean Gilbert-type fan delta (Gillet 2004; Suc et al. 2009) are inconsistent with the idea expressed by Krijgsman et al. (2010: p. 189) of a Mediterranean - Paratethys marine gateway at this place.

- When the Mediterranean reflooding occurred at 5.46 Ma (Bache et al., accepted), refilling of the Balkans gateway by Mediterranean marine waters caused the waterlevel rise of the Dacic Basin without immediately passing the Scythian sill (Bache et al., accepted). Simultaneously, the Tisza, Topolniţa, Strymon and Maritsa palaeorivers developed Gilbert-type fan deltas (Fig. 13c).

- Finally, when the continuously rising global sea-level driven by the ice melting passed over the Scythian sill (5.31 Ma), the connection was re-established with the Black Sea and the marine micro-organisms entered again the Black Sea (Fig. 13d; Popescu et al., 2010; Bache et al., accepted).

This scenario is inconsistent with that proposed by Leever et al. (2010) in which the sealevel changes of the Black Sea controlled the water-level of the Dacic Basin and the Pannonian Basin overflowed into the latter because of the difference in their altitude. On the contrary, we propose a scenario controlled by the sea-level changes in the Mediterranean Basin through its direct connection with the Dacic Basin via the Balkans gateway (Fig. 13).

\section{Conclusion}

which existed in the Mediterranean region before the MSC and persisted during the Pliocene (Suc and Bessais, 1990; Fauquette et al., 2006). 
Sedimentological, morphological, and palaeontological arguments point to the existence of both piedmont alluvial fans of pre-Maeotian (Serravallian -Tortonian) age and Gilbert-type fan deltas of Bosphorian (Zanclean) age in the region of Turnu Severin. This study confirms that the MSC severely affected the Eastern Paratethys during the Bosphorian regional Substage. Mediterranean marine waters entered the Dacic Basin and the Black Sea twice: just before and just after the peak of the MSC. Two Zanclean Gilbert-type fan deltas were coalescing upstream Turnu Severin. The most developed Gilbert-type fan delta was constructed by a Carpathians river which, as a response to the MSC, cut the Iron Gates and catched the residual Pannonian Basin and the ancestor of the Tisza River. The water-level changes in the Pannonian and Dacic basins were not forced by those of the Black Sea but directly by those of the Mediterranean Sea through the Balkans gateway. The Mediterranean Zanclean marine waters entered the Dacic Basin ca. 70 kyrs earlier than the Black Sea. The fluvial network of the Balkans region was significantly influenced by the sea-level drop of both the Mediterranean and Black seas during the peak of the MSC.

In conclusion, this study emphasizes once more how difficult it is to decipher the multiple aspects of the MSC. This difficulty results from an imprecise chronology due to such a short period of time and an insufficiently known palaeogeography, and persists despite recent significant advances. One of the most crucial aspects to be handled is the stratigraphic succession of channeled sedimentary complexes which are not controlled by the usual superposition of deposits. The high-resolution study of long sedimentary sections is essential, but it cannot alone elucidate the MSC, one of the core issues of the Cenozoic in the Mediterranean region. 


\section{Acknowledgements}

This paper is dedicated to the late F. Marinescu who invited one of us (J.-P.S.) since 1982 to collaborate for clarifying stratigraphic and palaeogeographic relationships between the Dacic Basin and the Mediterranean. The study of the Dîlbociţa nannoflora was done by M. Mărunţeanu in 1998. We acknowledge two anonymous reviewers for their recommendations in improving the manuscript. This paper is a contribution to the ANR "EGEO" Project and to the Project "Bassins néogènes et manteau en Méditerranée" (TerMEx CNRS/INSU).

\section{References}

Agusti, J., Garcés, M., Krijgsman, W., 2006. Evidence for African-Iberian exchanges during the Messinian in the Spanish mammalian record. Palaeogeography, Palaeoclimatology, Palaeoecology 238, 5-14.

Bache, F. Popescu, S.-M., Rabineau, M., Gorini, C., Suc, J.-P., Clauzon, G., Olivet, J.-L., Rubino, J.-L., Melinte-Dobrinescu, M.C., Estrada, F., Londeix, L., Armijo, R., Meyer, B., Jolivet, L., Jouannic, G., Leroux, E., Aslanian, D., Baztan, J., Dos Reis, A.T., Mocochain, L., Dumurdžanov, N., Zagorchev, I., Lesić, V., Tomić, D., Çağatay, M.N., Brun, J.-P., Sokoutis, D., Csato, I., Ucarkus, G., Çakir, Z., accepted. A two-step process for the reflooding of the Mediterranean after the Messinian Salinity Crisis. Basin Research.

CIESM (Antón, J., Çağatay, M.N., De Lange, G., Flecker, R., Gaullier, V., Gunde-Cimerman, N., Hübscher, C., Krijgsman, W., Lambregts, P., Lofi, J., Lugli, S., Manzi, V., McGenity, T.J., Roveru, M., Sierro, F.J., Suc J.-P., 2008. Executive Summary. In: Briand, F. (Ed.), The Messinian Salinity crisis from mega-deposits to microbiology - A consensus report. CIESM Workshop Monographs, 33, 7-28. 
Clauzon, G., 1990. Restitution de l'évolution géodynamique néogène du bassin du Roussillon et de l'unité adjacente des Corbières d'après les données écostratigraphiques et paléogéographiques. Paléobiologie continentale, 17, 125-155.

Clauzon, G., Suc, J.-P., Popescu, S.-M., Mărunţeanu, M., Rubino, J.-L., Marinescu, F., Melinte, M.C., 2005. Influence of Mediterranean sea-level changes on the Dacic Basin (Eastern Paratethys) during the late Neogene: the Mediterranean Lago Mare facies deciphered. Basin Research 17, 437-462.

Clauzon, G., Suc, J.-P., Melinte-Dobrinescu, M.C., Jouannic, G., Jolivet, L., Rubino, J.-L., Popescu, S.-M., Gorini, C., Bache, F., Estrada, F., 2009. New insights from the Andalusian Sorbas and Vera basins. 13ème Congrès RCMNS Naples, Acta Nat. Ateneo Parmense, 45 (1-4), 334-335.

Cojan, I., Renard, M., 1997. Sédimentologie. Enseignement des Sciences de la terre, Masson (Ed.), Paris, 418 p.

Csato, I., Kendall, C.G.StC., Moore, P.D., 2007. The Messinian problem in the Pannonian Basin, Eastern Hungary - Insights from stratigraphic simulations. Sedimentary Geology 201, 111-140.

Drivaliari, A., Ţicleanu, N., Marinescu, F., Mărunţeanu, M., Suc, J.-P., 1999. A Pliocene climatic record at Țicleni (Southwestern Romania). In: Wrenn, J.H., Suc, J.-P., Leroy, S.A.G. (Eds.), The Pliocene: Time of Change. American Association of Stratigraphic Palynologists Foundation, 103-108.

Fauquette, S., Suc, J.-P., Bertini, A., Popescu, S.-M., Warny, S., Bachiri Taoufiq, N., Perez Villa, M.-J., Chikhi, H., Subally, D., Feddi, N., Clauzon, G., Ferrier, J., 2006. How much did climate force the Messinian salinity crisis? Quantified climatic conditions from pollen records in the Mediterranean region. Palaeogeography, Palaeoclimatology, Palaeoecology $238,281-301$. 
Favre, E., François, L., Fluteau, F., Cheddadi, R., Thévenod, L., Suc, J.-P., 2007. Messinian vegetation maps of the Mediterranean region using models and interpolated pollen data. Geobios 40 (3), 433-443.

Gignoux, M., 1950. Géologie stratigraphique, 4th edition, Masson (Ed.), Paris, 735 p.

Gilbert, G.K., 1885. The topographic features of lake shores. U.S. Geological Survey Report, Washington, 5, 75-180.

Gilbert, G.K., 1890. Lake Bonneville. Monogr. U.S. Geol. Survey, Washington, 1, 438 pp.

Gillet, H., 2004. La stratigraphie tertiaire et la surface d'érosion messinienne sur les marges occidentales de la Mer Noire: Stratigraphie sismique haute résolution. $\mathrm{PhD}$ Thesis, University of Bretagne Occidentale, 259 p.

Gillet, H., Lericolais, G., Réhault, J.-P., 2007. Messinian event in the black sea : Evidence of a Messinian erosional surface. Marine Geology 244, 142-165.

Hámor, G., Jámbor, Á., Pogácsás, Gy., 2001. Paleogeographic/structural evolutionary stages and related volcanism of the Carpathian-Pannonian region. Acta Geologica Hungarica 44 (23), 193-222.

Harvey, A.M., Mather, A.E., Stokes, M., 2005. Alluvial fans: geomorphology, sedimentology, dynamics - introduction. A review of alluvial-fan research. In: Alluvial Fans, Harvey, A.M., Mather, A.E., Stokes, M. (Eds.). The Geological Society of London, Special Publication $251,1-8$.

Haxby, W.F., Melkonian, A.K., Coplan, J., Chan, S.-M., Ryan, W.B.F., 2010. GeoMapApp freeware software, v.2.3. Lamont-Doherty Earth Observatory, Palisades, jgs.geoscienceworld.org/cgi/content/full/168/2/333.

Horváth, F., Bada, G., Szafián, P., Tari, G., Ádám, A., Cloetingh, S., 2006. Formation and deformation of the Pannonian Basin: constraints from observational data. In: European 
Lithosphere Dynamics, Gee, D.G., Stephenson, R.A. (Eds.), Geological Society, London, Memoirs 32, pp. 191-206.

Jipa, D., 1997. Late Neogene - Quaternary evolution of Dacian Basin (Romania). An analysis of sediment thickness pattern. Geo-Eco-Marina 2, 127-134.

Jipa, D., 2009. Danube paleo-river appearance and the Messinian Crisis. $13^{\text {th }}$ Congress RCMNS, Naples, Acta Naturalia de “L’Ateneo Parmense” 45 (1-4), 371-372.

Jipa, D., Olariu, C., 2009. Dacian Basin. Depositional architecture and sedimentary history of a Paratethys Sea. Geo-Eco-Marina, Special Publication 3, 264 p.

Krijgsman, W., Stoica, M., Vasiliev, I., Popov, V.V., 2010. Rise and fall of the Paratethys Sea during the Messinian Salinity Crisis. Earth Planetary Science Letters 290, 183-191.

Leever, K.A., Matenco, L., Rabagia, T., Cloetingh, S., Krijgsman, W., Stoica, M., 2010. Messinian sea level fall in the Dacic Basin (Eastern Paratethys): palaeogeographical implications from seismic sequence stratigraphy. Terra Nova 22, 12-17.

Lourens, L.J., Hilgen, F.J., Laskar, J., Shackleton, N.J., Wilson, D., 2004. The Neogene period. In: Gradstein, F.M., Ogg, J.G., Smith, A.G. (Eds.), A geological Time Scale 2004. Cambridge University Press, Cambridge, pp. 409-440.

Magyar, I., Sztanó, O., 2008. Is there a Messinian unconformity in the Central Paratethys? Stratigraphy 5 (3-4), 245-255.

Marinescu, F., 1978. Stratigrafia Neogenului superior din sectorul vestic al Bazinului Dacic. Academiei Române (Ed.), 134 p.

Marinescu, F., Mărunţeanu, M., Papaianopol, I., Popescu, G., 1998. Tables with the correlations of the Neogene deposits in Romania. Romanian Journal of Stratigraphy 78, 181-186. 
Mărunţeanu, M., Papaianopol, I., 1995. The connection between the Dacic and Mediterranean Basins based on calcareous nannoplankton assemblages. Romanian Journal of Stratigraphy $76(7), 169-170$.

Mărunţeanu, M., Papaianopol, I., 1998. Mediterranean calcareous nannoplankton in the Dacic Basin. Romanian Journal of Stratigraphy 78, 115-121.

Martini, E., 1971. Standard Tertiary and Quaternary calcareous nannoplankton zonation, In: Farinacci, A. (Ed.), Proceedings of the 2nd International Conference on Planktonic Microfossils, Roma 1970 (2), Tecnoscienza (Ed.), Rome, pp. 739-785.

Melinte-Dobrinescu, M.C., Suc, J.-P., Clauzon, G., Popescu, S.-M., Armijo, R., Meyer, B., Biltekin, D., Çağatay, M.N., Ucarkus, G., Jouannic, G., Fauquette, S., Çakir, Z., 2009. The Messinian Salinity Crisis in the Dardanelles region: Chronostratigraphic constraints. Palaeogeography, Palaeoclimatology, Palaeoecology 278, 24-39.

Milovanović, B., Ćirić, B.M., Gorn, V., 1968. Carte géologique de la R.S. de Serbie. 3, Vršac Oršava. Institut de recherches géologiques et géophysiques de Belgrade.

Murphy, L.N., Kirk-Davidoff, D.B., Mahowald, N., Otto-Bliesner, B.L., 2009. A numerical study of the climate response to lowered Mediterranean Sea level during the Messinian Salinity Crisis. Palaeogeography, Palaeoclimatology, Palaeoecology 279, 41-59.

Năstăseanu, S., Bercia, I., 1968. Carte géologique de Roumanie au 1/200.000ème. 32. Baia de Aramă. Note explicative, pp. 1-48, Institut Géologique, Bucharest.

Olteanu, R., Jipa, D., 2006. Dacian Basin environmental evolution during Upper Neogene within the Paratethys domain. Geo-Eco-Marina 12, 91-105.

Orszag-Sperber, F., 2006. Changing perspectives in the concept of "Lago-Mare" in Mediterranean late Miocene evolution. Sedimentary Geology 188-189, 259-277.

Papaianopol, I., Jipa, D., Marinescu, F., Ţicleanu, N., Macaleţ, R., 1995. Upper Neogene from the Dacic Basin. Romanian Journal of Stratigraphy 76 (Suppl. 1), 2-43. 
Pfleiderer, S., Geostatistical analysis of elevation and lithology of Quaternary terraces in Vienna (Austria). Austrian Journal of Earth Sciences 101, 81-87.

Popescu, S.-M., 2001. Végétation, climat et cyclostratigraphie en Paratéthys centrale au Miocène supérieur et au Pliocène inférieur d'après la palynologie. PhD thesis, University C. Bernard - Lyon 1, 235 p.

Popescu, S.-M., 2006. Late Miocene and early Pliocene environments in the southwestern Black Sea region from high-resolution palynology of DSDP Site 380A (Leg 42B). Palaeogeography, Palaeoclimatology, Palaeoecology 238, 64-77.

Popescu, S.-M., Biltekin, D., Winter, H., Suc, J.-P., Melinte-Dobrinescu, M.C., Klotz, S., Combourieu-Nebout, N., Rabineau, M., Clauzon, G., Deaconu, F., 2010. Pliocene and Lower Pleistocene vegetation and climate changes at the European scale: Long pollen records and climatostratigraphy. Quaternary International 219, 152-167.

Popescu, S.-M., Krijgsman, W., Suc, J.-P., Clauzon, G., Mărunţeanu, M., Nica, T., 2006. Pollen record and integrated high-resolution chronology of the Early Pliocene Dacic Basin (Southwestern Romania). Palaeogeography, Palaeoclimatology, Palaeoecology 238 (1-4), $78-90$.

Popescu, S.-M., Suc, J.-P., Melinte, M., Clauzon, G., Quillévéré, F., Sütő-Szentai, M., 2007. Earliest Zanclean age for the Colombacci and uppermost Di tetto formations of the "latest Messinian" northern Apennines: New palaeoenvironmental data from the Maccarone section (Marche Province, Italy). Geobios 40 (3), 359-373.

Popescu, S.-M., Dalesme, F., Jouannic, G., Escarguel, G., Head, M.J., Melinte-Dobrinescu, M.C., Sütő-Szentai, M., Bakrac, K., Clauzon, G., Suc, J.-P., 2009. Galeacysta etrusca complex, dinoflagellate cyst marker of Paratethyan influxes into the Mediterranean Sea before and after the peak of the Messinian Salinity Crisis. Palynology 33 (2), 105-134. 
Popov, S.V., Shcherba, I.G., Ilyina, L.B., Nevesskaya, L.A., Paramonova, N.P., Khondkarian, S.O., Magyar, I., 2006. Late Miocene to Pliocene palaeogeography of the Paratethys and its relation to the Mediterranean. Palaeogeography, Palaeoclimatology, Palaeoecology 238, 91106.

Raffi, I., Backman, J., Rio, D., 1998. Evolutionary trends of tropical calcareous nannofossils in the late Neogene. Marine Micropaleontology 35, 17-41.

Raffi, I., Backman, J., Fornaciari, E., Pälike, H., Rio, D., Lourens, L., Hilgen, F., 2006. A review of calcareous nannofossil astrobiochronology encompassing the past 25 million years. Quaternary Science Reviews 25, 3113-3137.

Ruggieri, G., 1962. La serie marina pliocenica e quaternaria della Val Marecchia. Atti dell'Academia di Scienze, Lettere e Arti di Palermo 19, 1-169.

Savu, H., Ghenea, C., 1967. Carte géologique de Roumanie au 1/200.000ème. 40. Turnu Severin. Note explicative, pp. 1-31, Institut Géologique, Bucharest.

Schneck, R., Micheels, A., Mosbrugger, V., 2010. Climate modelling sensitivity experiments for the Messinian Salinity Crisis. Palaeogeography, Palaeoclimatology, Palaeoecology 286, $149-163$.

Schrader, H.-J., 1978. Quaternary through Neogene history of the Black Sea, deduced from the paleoecology of diatoms, silicoflagellates, ebridians, and chrysomonads. In: Ross, D.A., Neprochnov, Y.P., et al. (Eds.), Initial Report of the Deep Sea Drilling Project, vol. 42 (2), pp. 789-901.

Semenenko, V.N., Olejnik, E.S., 1995. Stratigraphic correlation of the eastern Paratethys Kimmerian and Dacian stages by molluscs, dinocyst and nannoplankton data. Romanian Journal of Stratigraphy 76 (7), 113-114.

Seneš, J., 1973. Correlation hypotheses of the neogene Tethys and Paratethys. Giornale di Geologia 39 (2), 271-286. 
Snel, E., Mărunţeanu, M., Macaleț, Meulenkamp, J.E., van Vugt, N., 2006. Late Miocene to Early Pliocene chronostratigraphic framework for the Dacic Basin, Romania. Palaeogeography, Palaeoclimatology, Palaeoecology 238, 107-124.

Suc, J.-P., Bessais, E., 1990. Pérennité d'un climat thermo-xérique en Sicile, avant, pendant, après la crise de salinité messinienne. Comptes-Rendus de l'Académie des Sciences de Paris ser. 2, 310, 1701-1707.

Suc, J.-P., Clauzon, G., Armijo, R., Meyer, B., Melinte-Dobrinescu, M.C., Popescu, S.-M., Lericolais, G., Gillet, H., Çağatay, M.N., Jouannic, G., Brun, J.-P., Sokoutis, D., Ucarkus, G., Çakir, Z., 2009. The Messinian Salinity Crisis in the Northeastern Aegean Black Sea region. 13ème Congrès RCMNS Naples, Acta Naturalia de “L'Ateneo Parmense" 45 (1-4), 116-117.

Van Couvering, J.A., Castradori, D., Cita, M.B., Hilgen, F.J., Rio, D., 2000. The base of the Zanclean Stage and of the Pliocene Series. Episodes 23 (3), 179-187.

Vasiliev, I., Krijgsman, W., Langereis, C.G., Panaiotu, C.E., Maţenco, L., Bertotti, G., 2004. Towards an astrochronological framework for the eastern Paratethys Mio-Pliocene sedimentary sequences of the Focşani basin (Romania). Earth Planetary Science Letters 227, $231-247$. 


\section{Figure captions}
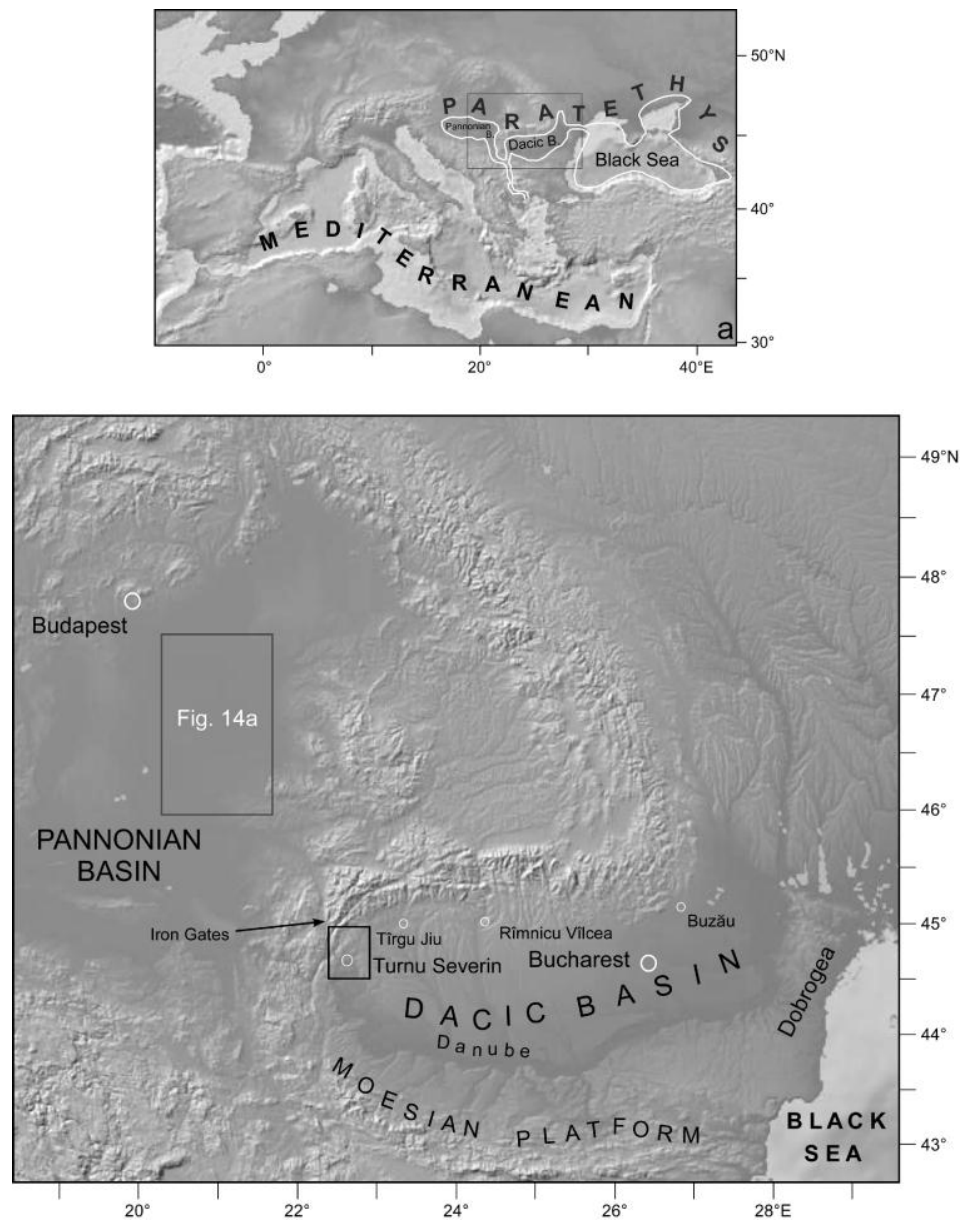

Fig. 1. Location map of the Turnu Severin studied area in the Dacic Basin. The map has been elaborated using GeoMapApp System http://www.geomapapp.org/, developed by Haxby et al. (2010).

a, Reconstructed map (in white) of the Paratethys just before the MSC according to Popescu et al. (2009) for the western part (Pannonian and Dacic basins) and Krijgsman et al. (2010) for the eastern part (Black Sea). The intra-Paratethysian gateways and the gateway between the Pannonian-Dacic basins and the Mediterranean are from Popescu et al. (2009). The grey box corresponds to Figure $1 \mathrm{~b}$.

b, Map of Hungary (Pannonian Basin) and southern Romania (Dacic Basin). Black box in the Dacic Basin: studied area in the Turnu Severin region. 


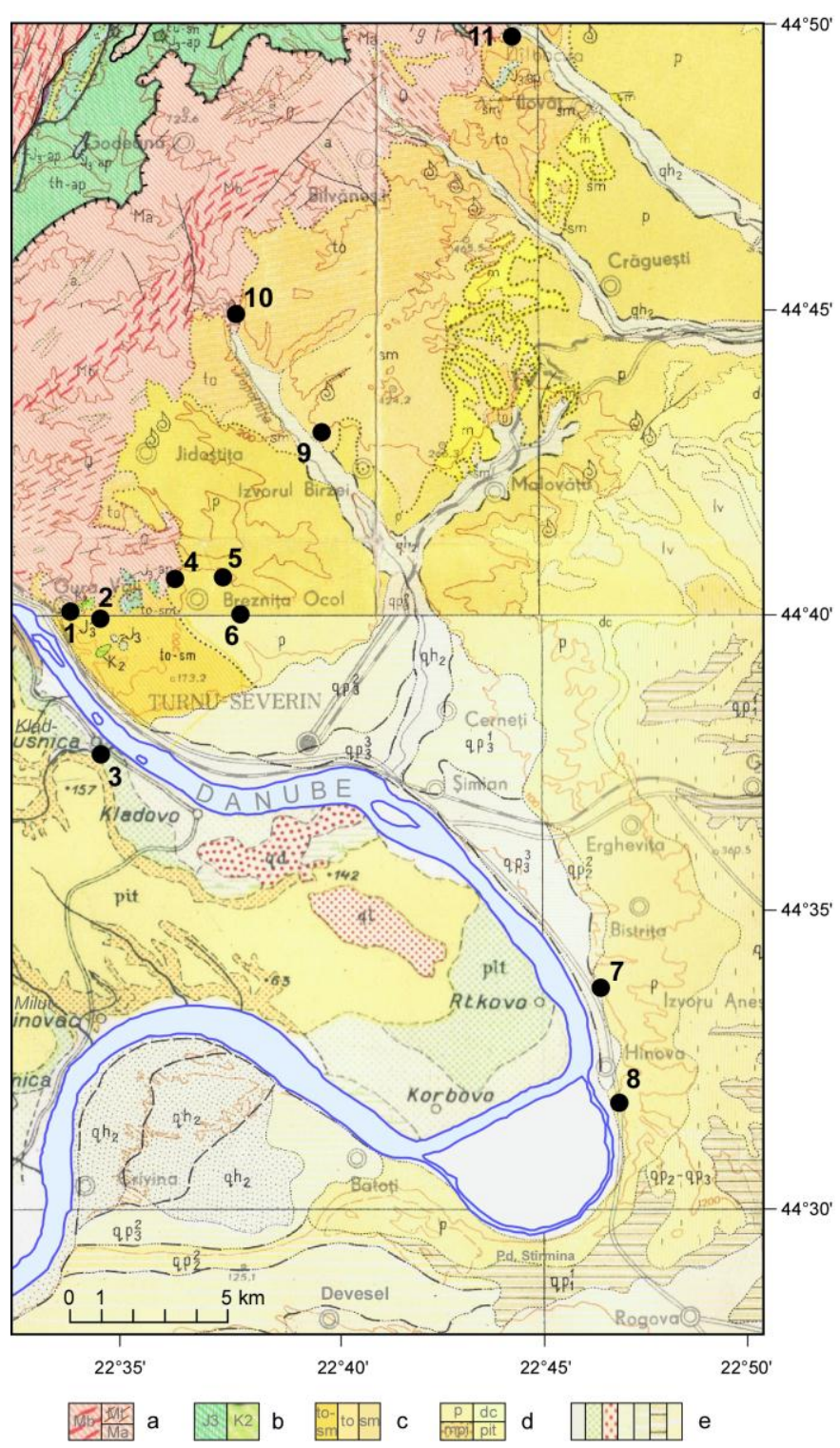

Fig. 2. Geological map of the area of Turnu Severin (from: Năstăseanu and Bercia, 1968;

Savu and Ghenea, 1967; Milovanović et al., 1968) at scale 1/200,000.

Main geological units: a, Metamorphic basement; b, Jurassic (J) and Cretaceous (K); c, Middle Miocene; d, Late Miocene and Pliocene (Serbia: mpi, lower Congeria beds; pit, Pliocene gravels, sands and clays; Romania: p, Pontian clays; dc, Dacian sands and lignites); e, Pleistocene to Holocene (Serbia: qt, loess).

Localities: 1, Gura Văii; 2, Capătul Drumului; 3, Kladusnica; 4, Vărănic ; 5, BrezniţaOcol; 6, Pd. Trestenic; 7, Hinova a; 8, Hinova b; 9, Izvoru Bîrzii; 10, Baloteşti; 11, Dîlbociţa (Ilovăţ). 

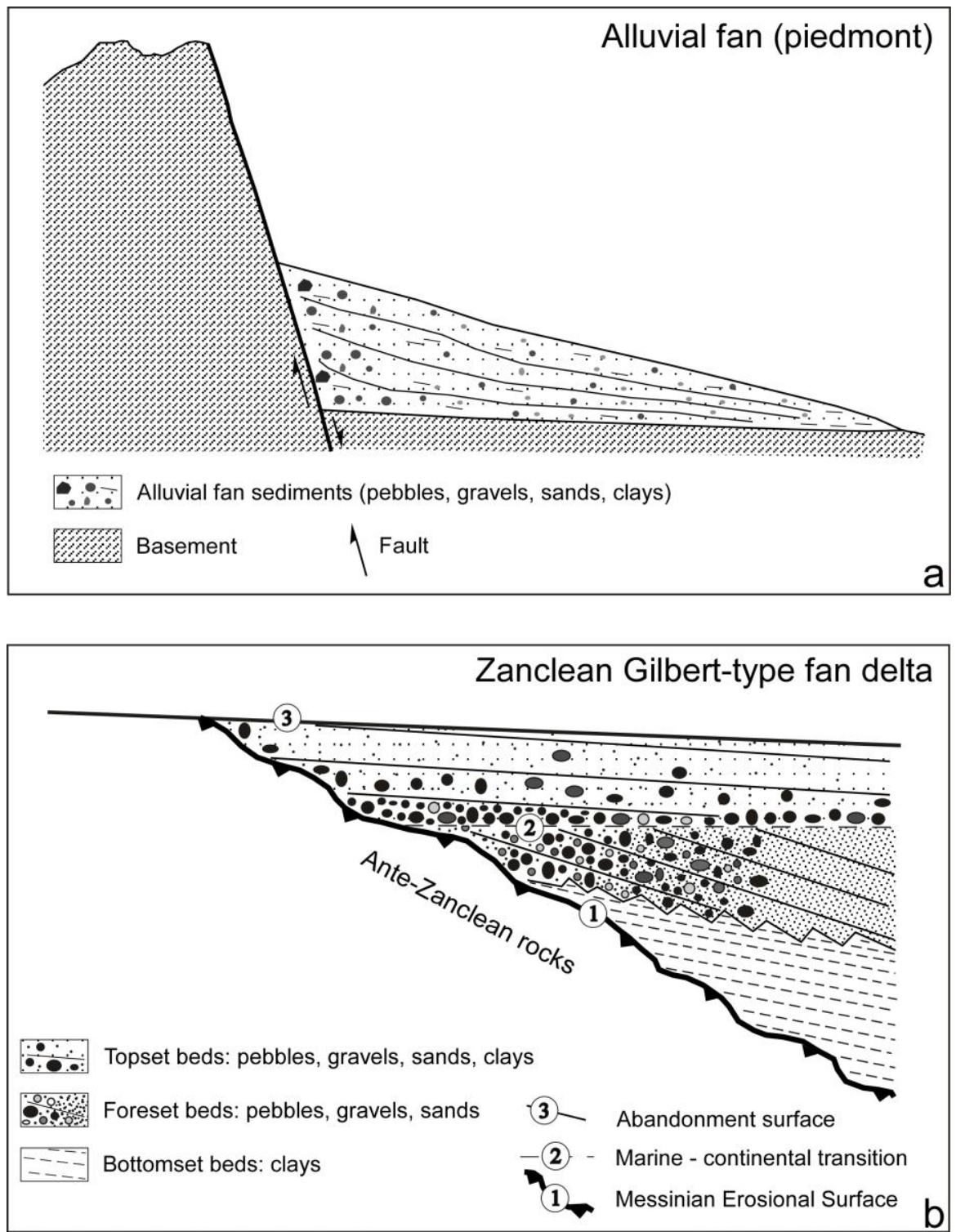

Fig. 3. Compared organizations and sediments of a piedmont alluvial fan (from: Cojan and Renard, 1997) and a Zanclean Gilbert-type fan delta (from: Clauzon, 1990). 

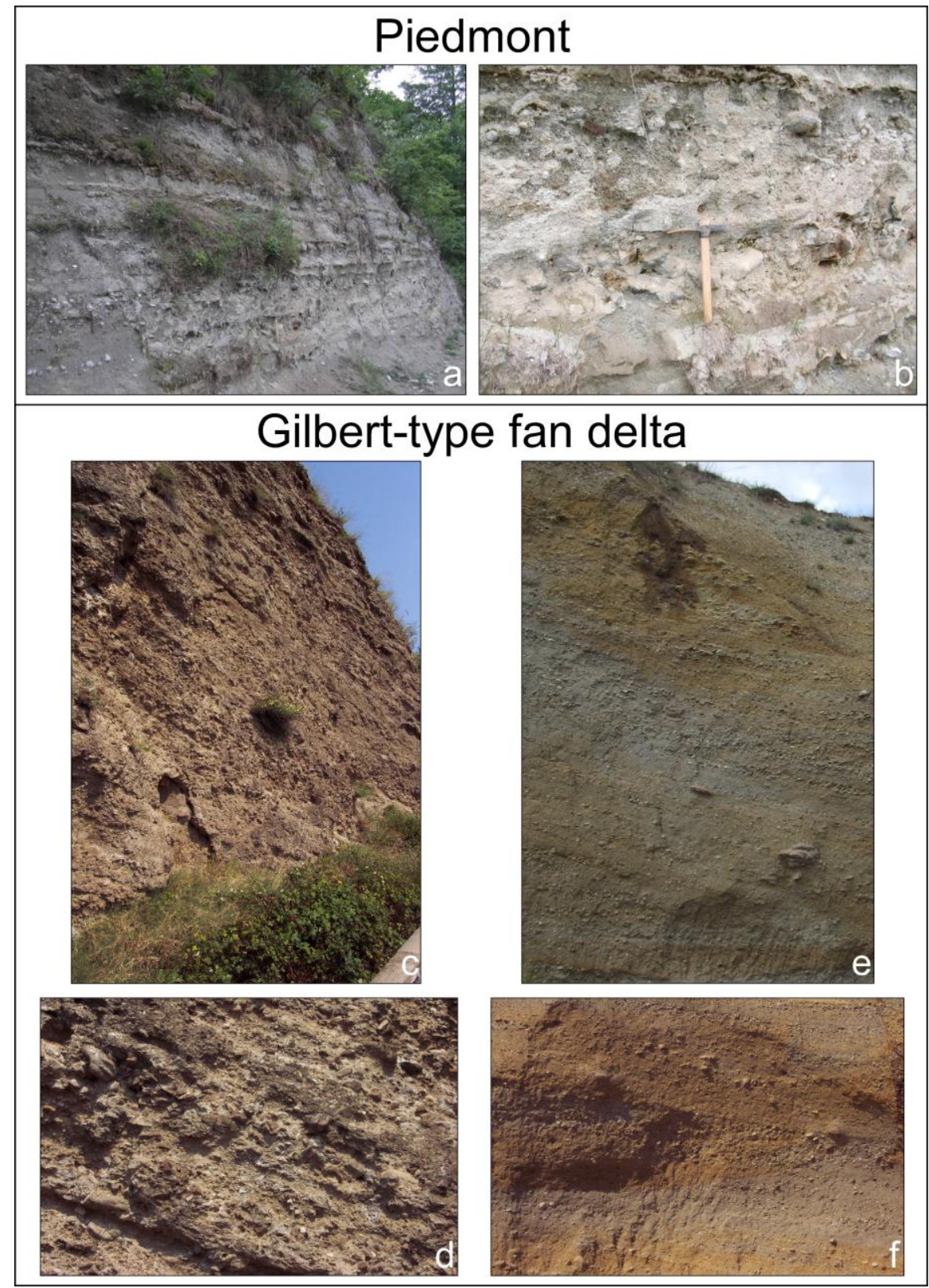

Fig. 4. Sedimentary facies of piedmont and Gilbert-type fan delta deposits in the study area.

Piedmont: a, Post-Badenian (Sarmatian?) piedmont at Dîlbociţa (Ilovăţ) (locality 11 in Figure $2 ; b$, detailed view.

Gilbert-type fan delta: c, Conglomeratic foreset beds downstream Gura Văii (Fig. 2);

$\mathrm{d}$, detailed view; e, Sandy foreset beds at the abandoned swimming pool of Turnu Severin (Fig. 2); f, detailed view. 

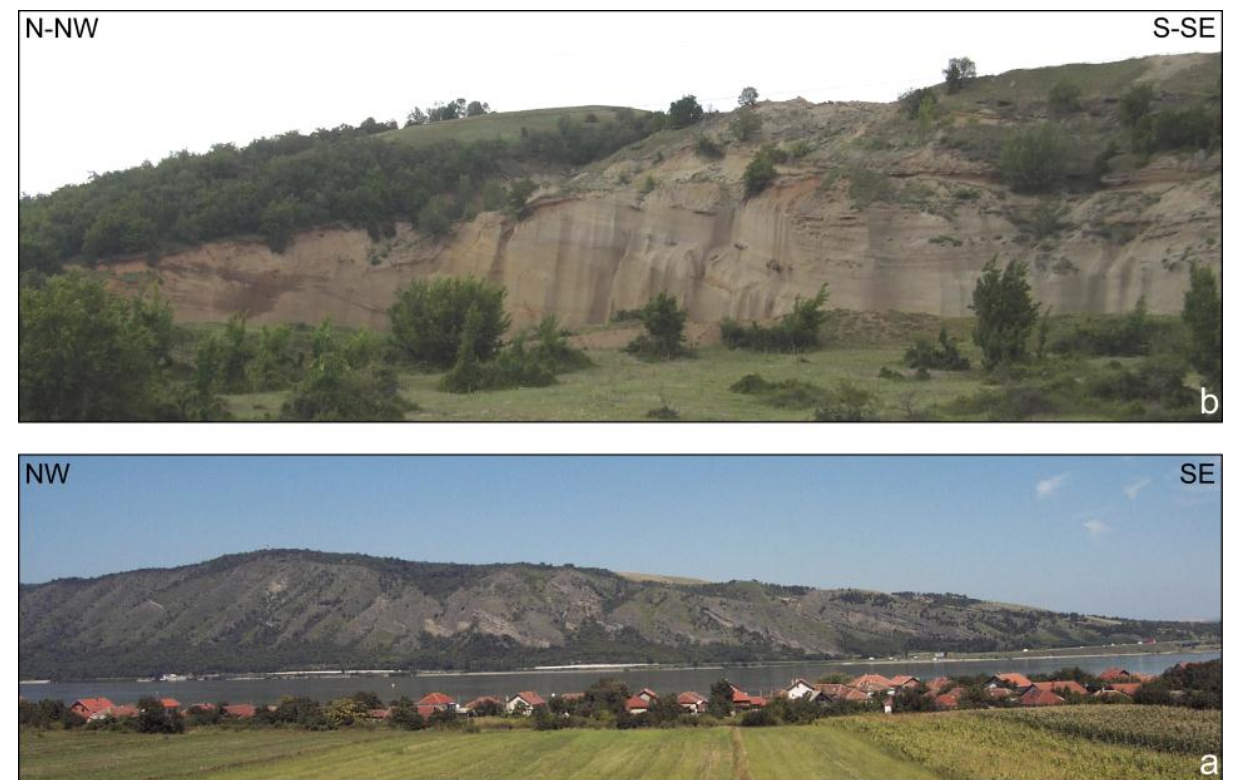

Fig. 5. Foreset beds of the Gilbert-type fan deltas in the area of Turnu Severin.

a, Conglomeratic to sandy foreset beds of the Gilbert-type fan delta between Gura Văii (NW) and Turnu Severin (SE) (Fig. 2);

b, Gravelly to sandy foreset beds of the Gilbert-type fan delta upstream Izvorul Bîrzei (locality 9 in Figure 2).

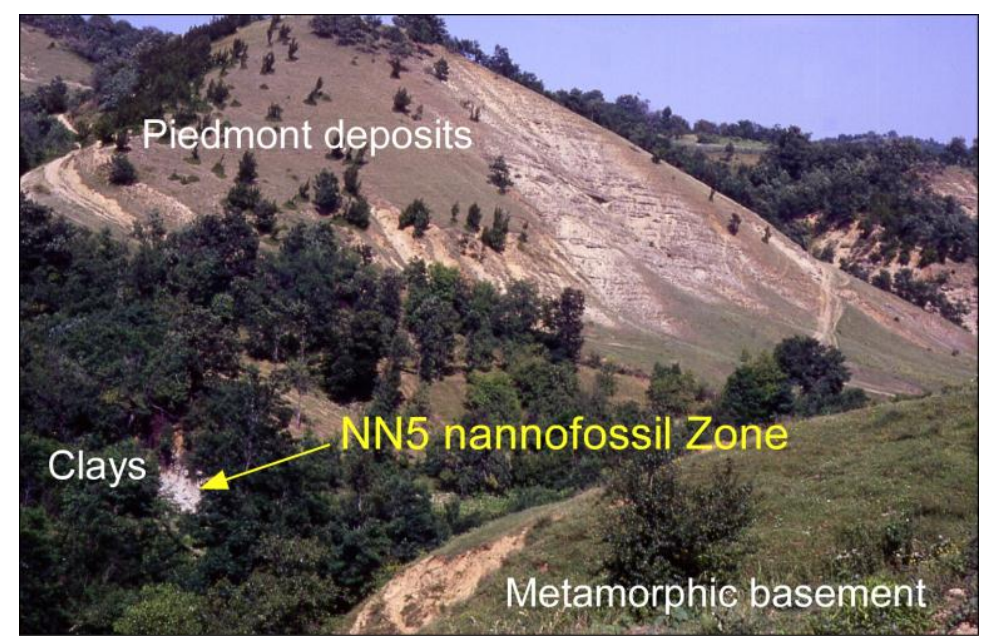

Fig. 6. Dîlbociţa Neogene succession overlying the metamorphic basement.

For the piedmont deposits, see details in Figures 4a-b. 


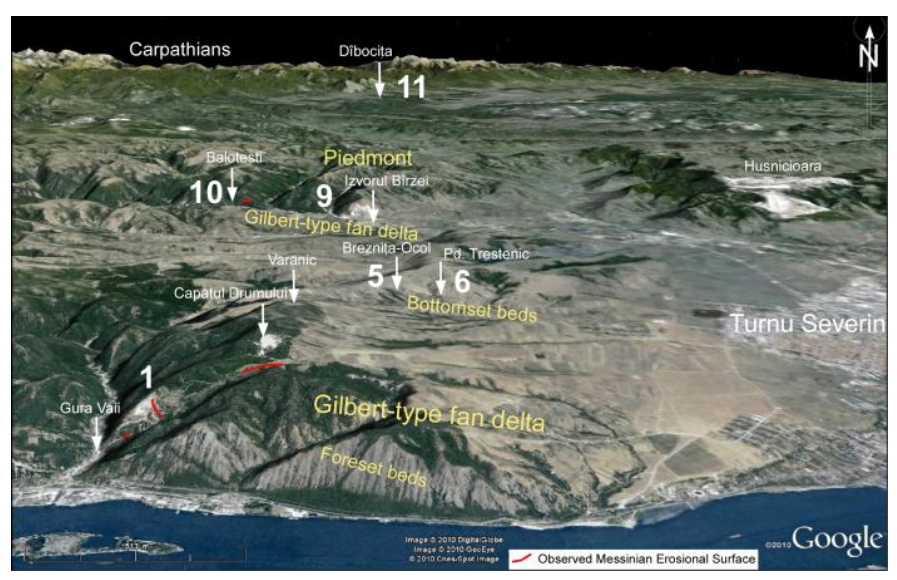

Fig. 7. GoogleEarth three-dimensional representation of the region westward Turnu Severin showing different terms of the Carpathians piedmont and the Tisza and Topolniţa Gilbert-type fan deltas. Vertical exaggeration x2.

Locality numbers: see Figure 2.
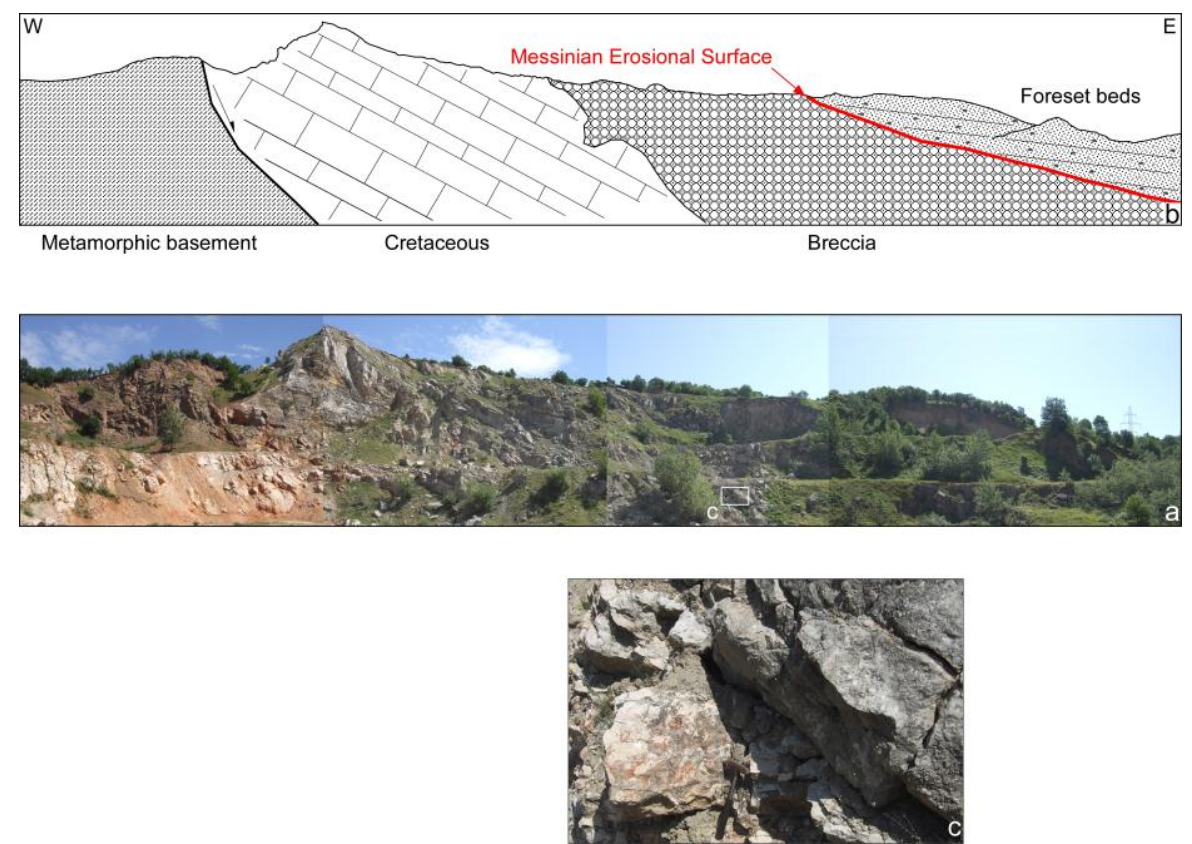

Fig. 8. Cross-section in the quarry overhanging Gura Văii.
a, Photograph panorama;
b, Interpreted cross-section;
c, Detail of the breccias. 


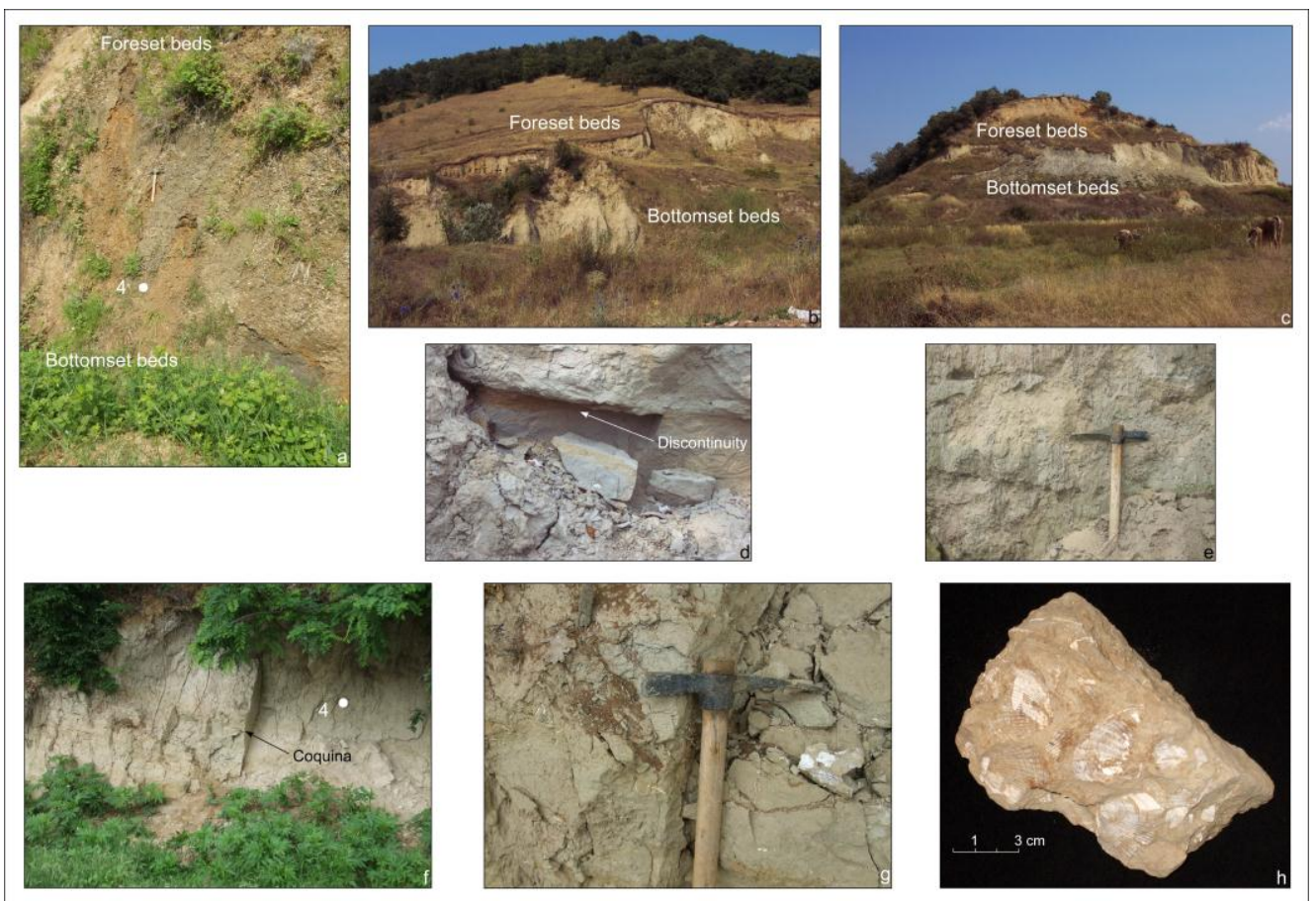

Fig. 9. Bottomset beds and their relationship with foreset beds.

a, Pd. Trestenic: location of sample 4 with nannofossils;

$\mathrm{b}$ and $\mathrm{c}$, Hinova a;

d, Hinova a, focus on the discontinuity underlying the lowermost nannoflora published in Clauzon et al. (2005);

e, Hinova a, foreset beds;

f, Hinova b, respective location of the coquina and sample 4 with nannofossils;

$\mathrm{g}$ and $\mathrm{h}$, detail of the coquina. 

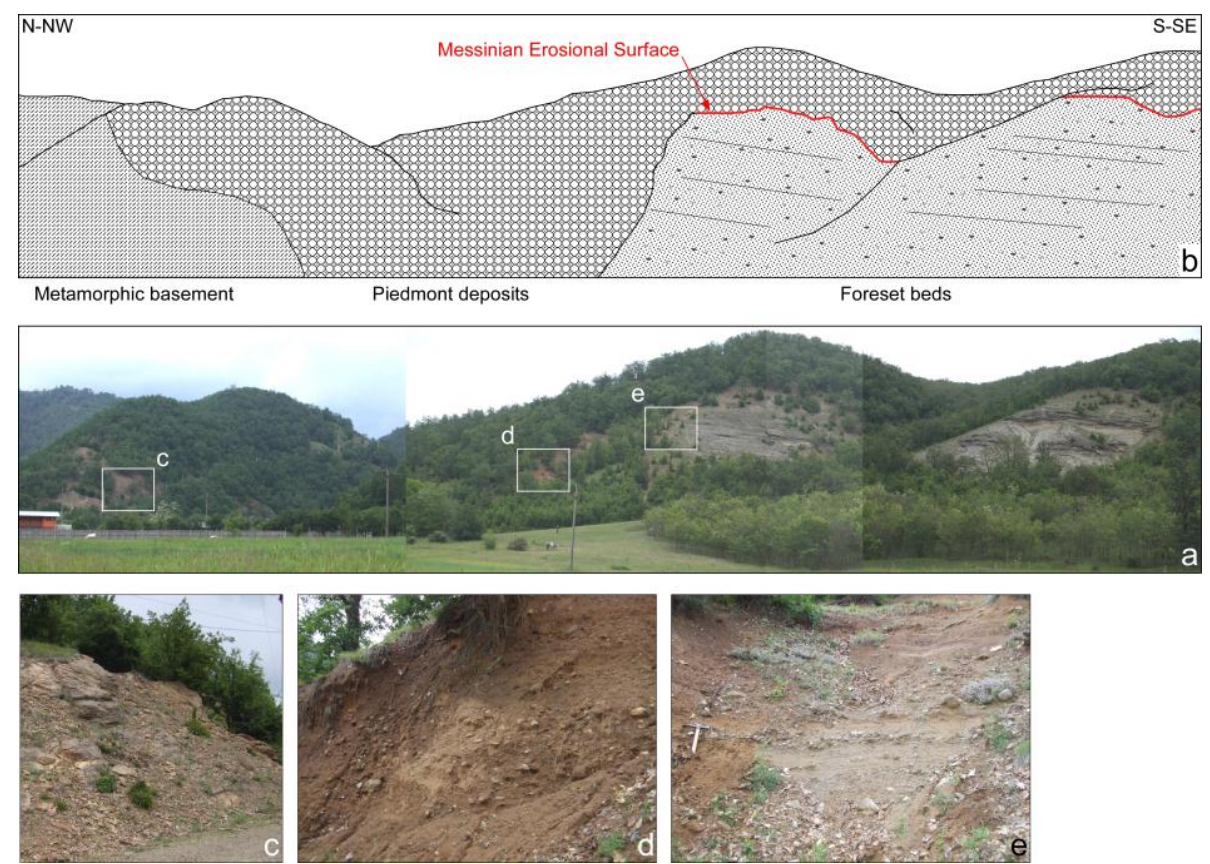

Fig. 10. Cross-section at Baloteşti

a, Photograph panorama;

b, Interpreted cross-section;

c, View of the metamorphic basement;

d, Piedmont alluvial deposits;

e, Sandy foreset beds nested within the piedmont alluvial deposits. 


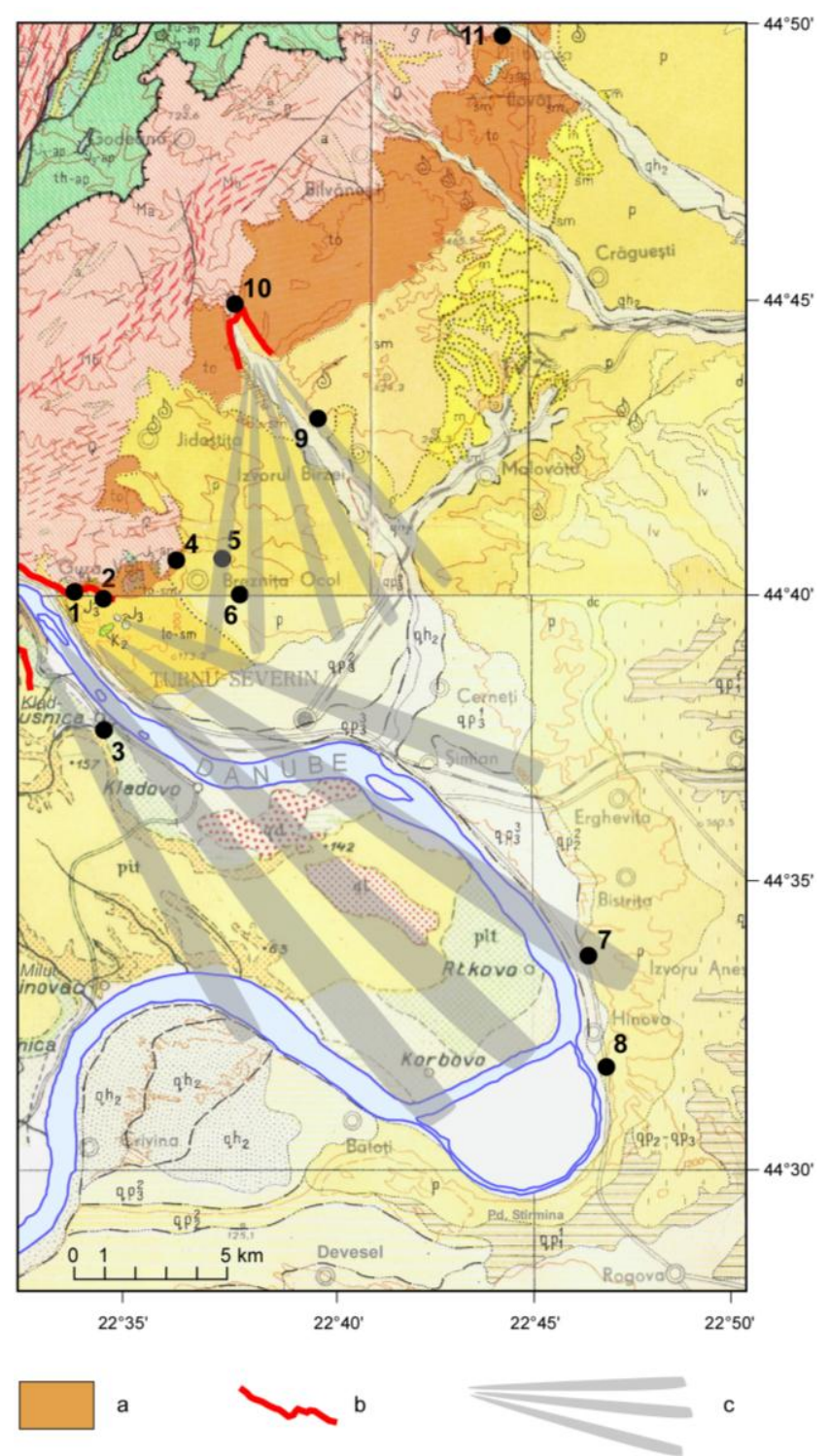

Fig. 11. Cartographic relationship between the piedmont deposits and prograding sediments of the two coalescing Gilbert-type fan deltas. Same gathered geological maps and same legend as for Figure 2.

a, Revised mapping of the piedmont alluvial deposits; b, Messinian Erosional Surface where it has been observed; c, Expansion of the prograding sediments of the Tisza and Topolniţa coalescing Gilbert-type fan deltas. 

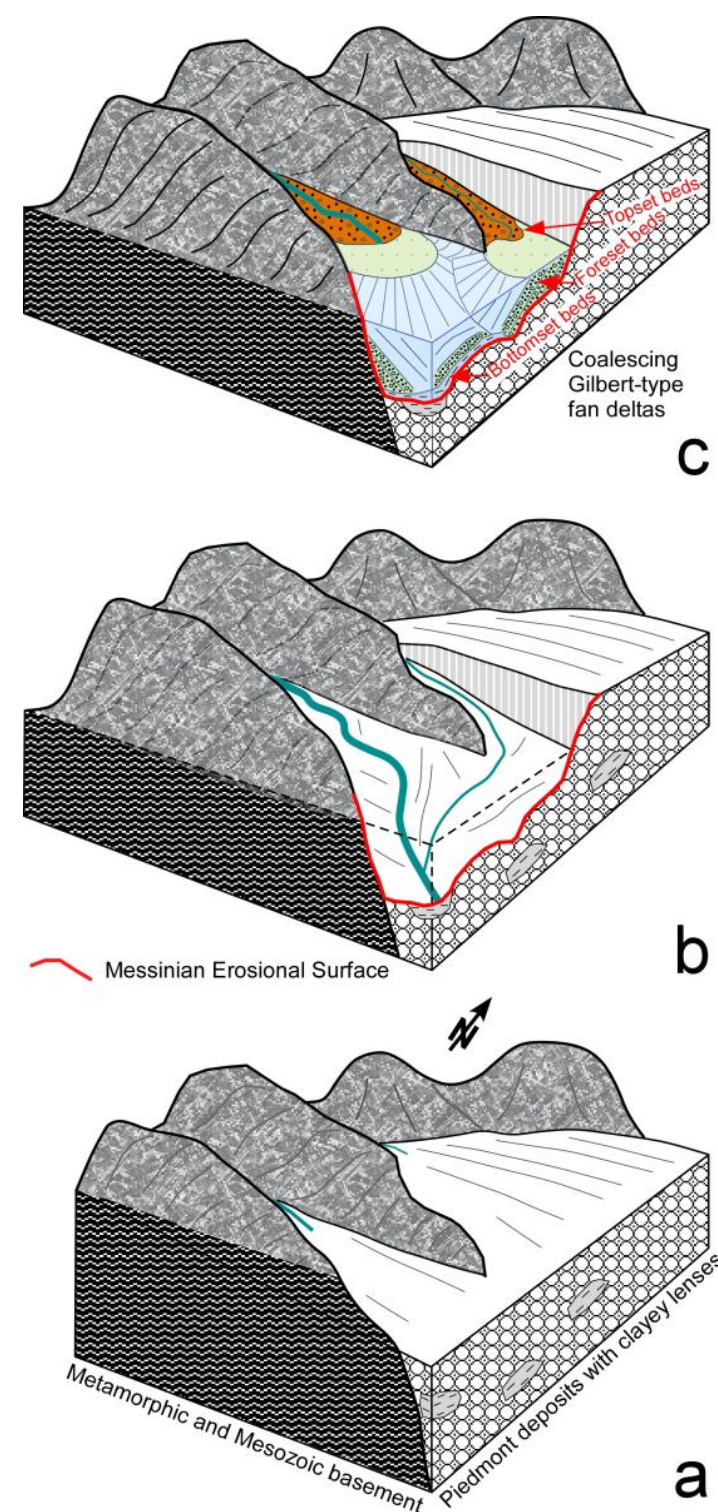

Fig. 12. Three-dimensional reconstructed evolution of the Turnu Severin area for the timeinterval $10-5 \mathrm{Ma}$.

a, From ca. 12 to ca. $6 \mathrm{Ma}$ (late Serravallian to early Messinian; Table 1), continuous building of the South Carpathians piedmont alluvial fan as a response to the uplifted relief;

b, At 5.6 Ma (late Messinian; Table 1), huge fluvial erosion by the palaeo-Tisza River (first cutting of the Iron Gates) and the Topolniţa River as a response to the desiccation of the Mediterranean Sea at the peak of the MSC; 
c, At 5.3 - 5 Ma (early Zanclean; Table 1), fast progradation of two coalescing Gilbert-type fan deltas, nested within the previously deposited piedmont alluvial fan, as a response to the recovered connection of the Dacic Basin with the Mediterranean Sea.


Fig. 13. Block-diagrams illustrating palaeogeographic changes considered in the Balkans South Carpathians - Black Sea region with respect to the MSC (prior to 5.60 Ma to 
post-5.31 Ma). Regional palaeogeographic maps from Popescu et al. (2009) and Bache et al. (accepted) have been used.

a, Before the MSC; b, During the peak of the MSC; $c$, At the time of the reflooding of the Mediterranean Basin (i.e. the Zanclean Deluge); d, When the Scythian sill was crossed by the rising sea-level of the Dacic Basin then reconnected with the Black Sea. In blue, marine water environments; in green, brackish to fresh water environments.

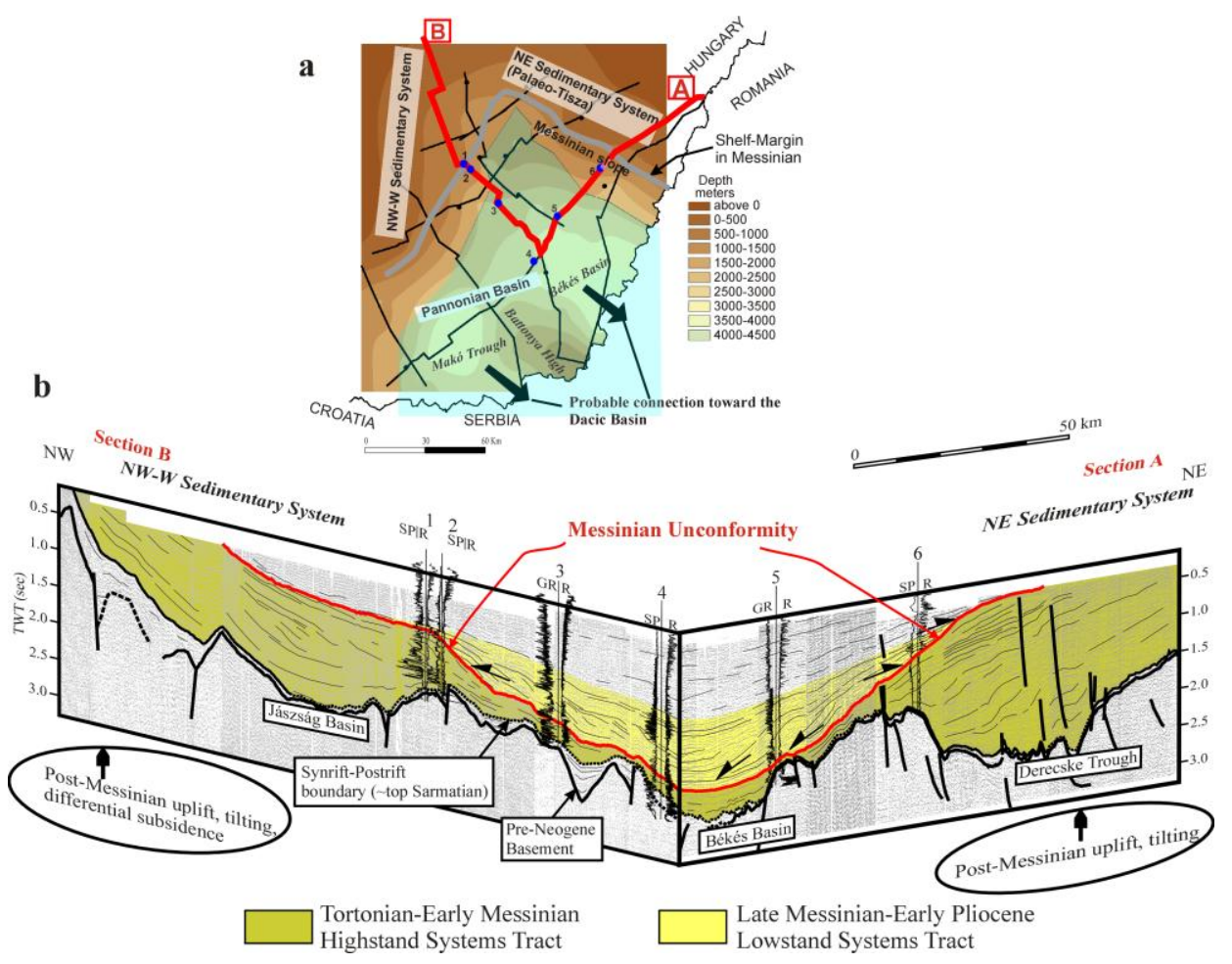

Fig. 14. a, Location of regional seismic sections and wells in the Pannonian Basin, Hungary, used in this study. The red lines indicate the location of seismic sections shown in Figure 14b. The Pannonian Basin was filling up from a NW-W and a NE fluvial transport system in the Late Miocene. These systems constituted the palaeo-Tisza. The contour map shows the depth of the Messinian unconformity surface constructed by correlations on the seismic sections and converted to depth by an averaged time-depth function in the basin. Palaeogeographic connections were probably established toward the Dacic Basin through the Békés Basin and/or Makó Trough. 
b, Representative seismic sections (location is indicated by red lines in Fig. 14a). The seismic data clearly show a significant unconformity in the Messinian. The surface represents a major water level fall and erosion. As a result, the remainder of the basin was filled up fast by lowstand prograding units.

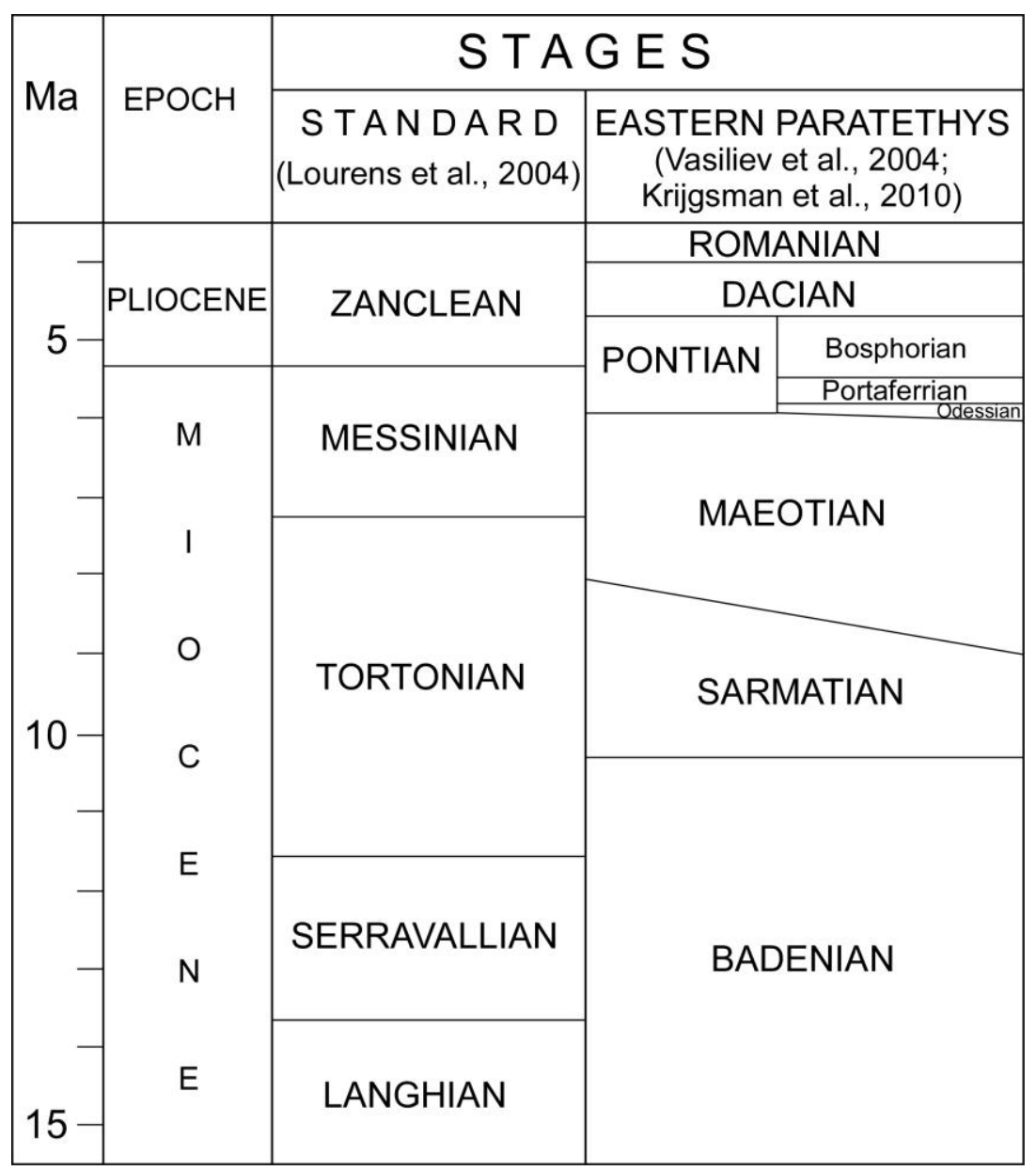

Table 1. Chronostratigraphic scales for the Mediterranean (Standard Stages) and Eastern Paratethys. 


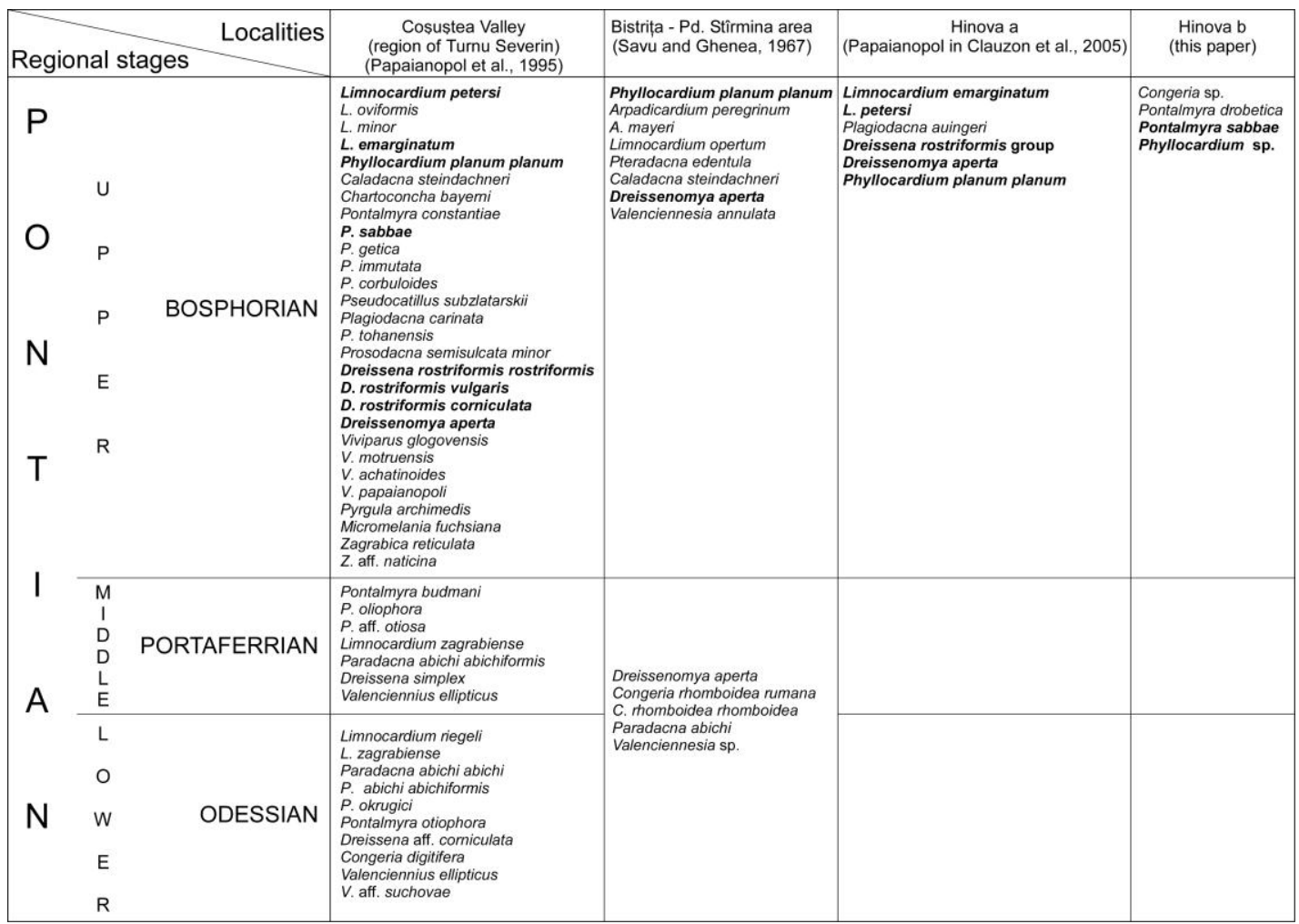

Table 2. Detailed Pontian mollusk fauna described by Papaianopol et al. (1995) in the region of Turnu Severin compared to records reported by Savu and Ghenea (1967) in the Turnu Severin geological map, to the Hinova a macrofauna from Papaianopol (in: Clauzon et al., 2005) and to that recently collected at Hinova b (this paper).

Strictly Bosphorian common taxa in bold characters. 

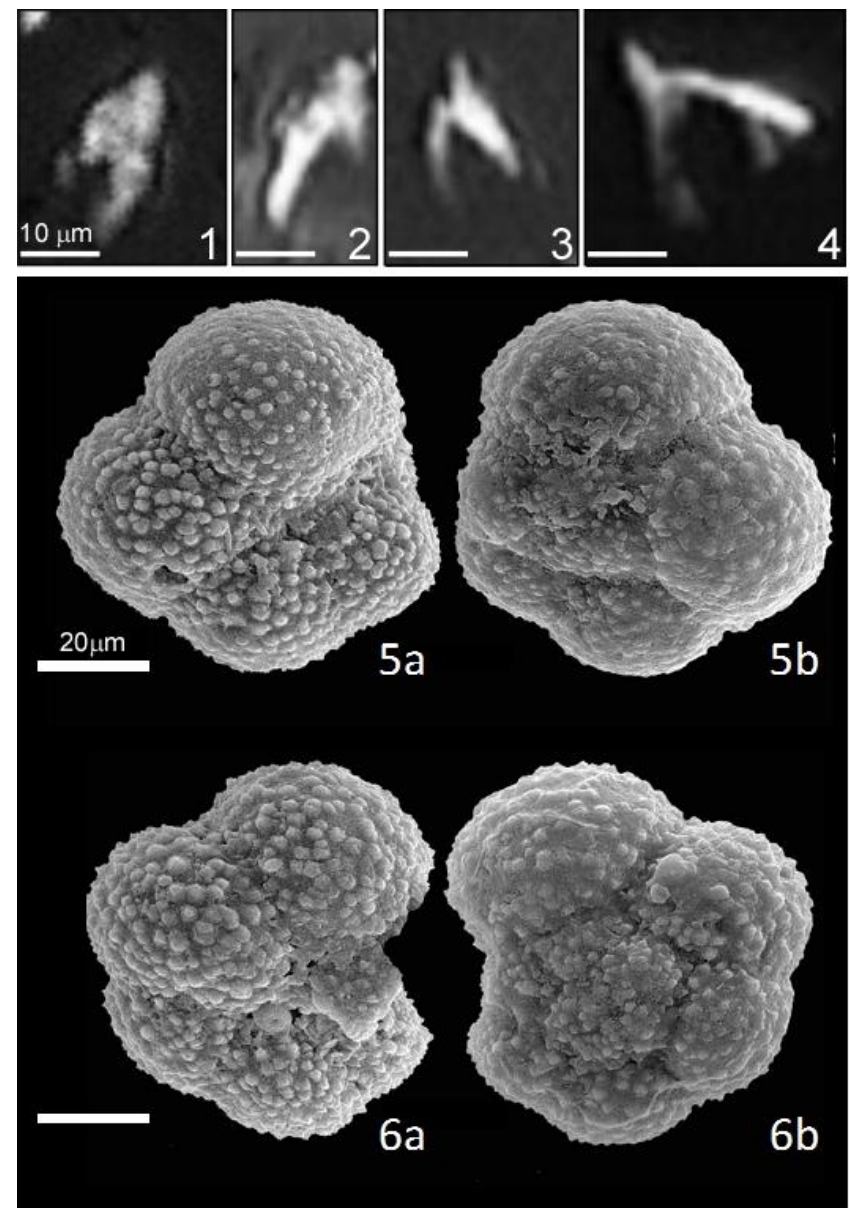

Plate 1. Figs. 1-4. Microphotographs of significant biostratigraphic nannoplankton species (light microscope, crossed nicols, scale bar $=10 \mu \mathrm{m}$ ).

Figs. 1, 2. Ceratolithus acutus Gartner \& Bukry 1974; Hinova b (sample 4).

Fig. 3. Ceratolithus cf. larrymayeri Backman \& Raffi 1998; Pd. Tristenic (sample 4).

Figs. 4. Ceratolithus larrymayeri Backman \& Raffi 1998; Pd. Tristenic (sample 4).

Figs. 5-6. SEM microphotographs of two representatives of the planktonic foraminifera (Tenuitella-Tenuitellinata sp.) collected from Hivona b (sample 4), in umbilical (a) and spiral (b) views. Note the very small size of these specimens (scale $\operatorname{bar}=20 \mu \mathrm{m})$. 